\title{
Ortaokul Öğretmenlerinin Görüşlerine Göre Okul Müdürlerinin Sergilediği Teknolojik Liderlik Davranış Düzeyi *
}

\section{Technological Leadership Behavior Level of Secondary Schools Principals According to Teachers' Views}

\author{
Mehmet DURNALI ${ }^{* *}$
}

Received: 31 July 2018

Research Article

Accepted: 09 January 2019

\begin{abstract}
This research aims to examine the level of technological leadership behaviors of the secondary school principals in the use of technology by teachers according to secondary school teachers' views on the basis of some variables. The quantitative method was used. The study group consisted of 442 teachers from secondary schools in Mamak district of Ankara. The data was collected through "School Principals Technological Leadership Behavior Scale (SPTLB-S)" developed by Durnal1 (2018). SPTLB-S consists of eighteen items under four factors which are motivation, orientation, precaution, and support. According to the main result; teachers' views regarding technological leadership behaviors of the secondary school principals in the use of technology by teachers is at a "high (4/5)" level for general and all sub-dimensions. There were no statistically meaningful differences found in terms of all independent variables (gender, age, working experience, education status, working-years spent in the same school, and the duration of working with the principal).
\end{abstract}

Keywords: technological leadership, leadership, technology, school principal, teacher.

ÖZ: Bu çalışmada; ortaokul öğretmenlerinin görüşlerine göre; öğretmenlerin teknoloji kullanımında okul müdürlerinin sergilediği teknolojik liderlik davranışlarının düzeylerini; bu düzeylerde çeşitli değişkenler (cinsiyet, yaş, mesleki kıdem, eğitim durumu, okuldaki görev süresi ve müdürle çalışma süresi) temelinde istatistiki açıdan anlamlı farklılık olup olmadığını tespit etmek amaçlanmıştır. Betimsel tarama modeline uygun nicel veri toplama ve analizi süreçleri uygulanmıştır. 2017-2018 eğitim öğretim yılı bahar döneminde, Ankara İli Mamak ilçesine bağlı ortaokullarda görevli 442 öğretmenin görüşleri, Durnalı (2018) tarafinca geliştirilen "Okul Müdürü Teknolojik Liderlik Davranış Ölçeği (OMTLD-Ö)” aracılığıyla verilere dönüştürülmüştür. OMTLD-Ö; motivasyon, yönlendirme, altyapı ve hukuk olmak üzere dört boyut altında on sekiz maddeden oluşmaktadır. Temel sonuçlara göre; öğretmenler, öğretmenlerin teknoloji kullanımında okul müdürlerinin sergilediği teknolojik liderlik davranışlarına; motivasyon, yönlendirme, altyapı ve hukuk alt boyutları ve davranışlar toplamı bağlamında katılmaktadırlar. Bu katılma durumlarının herhangi birisinde, öğretmenlerin cinsiyeti, yaşı, mesleki kıdemi, öğrenim durumu, okuldaki görev süresi ve okul müdürüyle çalışma süresi değişkenleri alt grupları temelinde görüş farklılığı oluşmamıştır.

Anahtar kelimeler: teknolojik liderlik, liderlik, teknoloji, okul müdürü, öğretmen.

\footnotetext{
${ }^{*}$ The manuscript is a part of author's Ph.D. dissertation.

*** Corresponding Author: Dr., Hacettepe University, Ankara, Turkey, durnali@gmail.com, https://orcid.org/00000002-1318-9362
}

Citation Information

Durnalı, M. (2019). Ortaokul öğretmenlerinin görüşlerine göre okul müdürlerinin sergilediği teknolojik liderlik davranış düzeyi. Kuramsal Eğitimbilim Dergisi [Journal of Theoretical Educational Science], 12(2), 401-430. 


\section{Giriş}

Teknolojik liderlik, eğitim ve öğretim amaçlarını en üst düzeyde gerçekleştirmek amacıyla eğitim ve öğretimin yönetimi süreçlerinde insan ve madde kaynaklarının sevk ve idaresinde, okul dışındaki alt ve üst sistemlerin (veli, sivil toplum örgütleri, dernek vb.) eğitim öğretim sürecine etkili katılımında bilgi ve iletişim teknolojilerinin üst düzeyde verimli olacak şekilde işe koşulabilmesi için yeterli ve gerekli politika, uygulama, tedbir ve stratejilerin oluşturulması ve eğitim örgütleri yönetim süreçlerine, çalışanlarına ve öğrencilere sağlanmasıdır. Diğer bir ifadeyle, teknolojik liderlik, etkili bir eğitim öğretim sistemi oluşturma ve sürdürme için teknolojinin faydalarının en üst düzeyde etkili olmasını sağlama noktasında önderlik etmektir. Bu çalışmada, teknolojik liderliğe yüklenilen anlam; bilgi teknolojileri liderliği, bilgi ve iletişim teknolojileri liderliği, elektronik liderliği, eğitim teknolojileri liderliği ve dijital liderlik kavramlarının barındırdığı anlamları içermektedir (Durnalı, 2018).

Öğretmenlere yardımcı olmak, öğretim programlarını tanımlamak ve okulun güvenli ve temiz olduğunu garanti etmek müdürlerin görevleri arasındadır. Liderliğin özellikleri, yeterli okul müdürleri ile mükemmel okul müdürleri arasındaki farkta yatmaktadır. Okul liderleri, okullara destek verip değişiklikleri geliştirirken, sorunları tanımlamalı ve çözmelidir (Scott, 2005). Teknolojik liderlik ve teknoloji yönetimi arasındaki farkları ayırt etmek kolay değildir. Yaygın olarak ayırım şu noktada yapılmaktadır. Yönetim, bakım ve koordinasyon işlevlerini vurgularken, liderlik ise geleceğe hazırlanmak ve değişime tepki vermek için başkalarıyla birlikte çalışmayı içermektedir (Valdez, 2004). Teknolojik açıdan anlayışlı, küresel düzeyde yetenekli ve uygulanabilir becerilere sahip geleceği parlak vatandaşların 21. yüzyılın bilgi temelli ekonomisine katkı sağlanması temelinde hazırlanması, okulda değişikliklere teknolojiyi bütüncül bir şekilde katalize ederek öncülük eden bir okul liderini gerektirir (McLeod \& Richardson, 2011). Teknolojik liderlik ile birlikte okul yöneticileri gelenekselin dişına çıkmalı ve farklı yeni sorumluluklar almalı ve teknolojiyi daha verimli kullanmalıdırlar (Ünal, Uzun, \& Karataş, 2015). Okul müdürlerinin okullarda teknolojiyi tanitan, geliştiren ve sürdüren teknolojik liderler olması ve bilişsel, psikomotor ve özellikle duyusal teknolojik niteliklere sahip olmaları beklenmektedir (Bektaş, 2014). Chang'e (2012) göre; dijital teknoloji çağında, teknolojik liderlik giderek önem kazanmaktadır.

Teknolojik liderlik, okulun tamamında bilgi teknolojisinin etkili kullanımını kolaylaştıran örgütsel eylem, politika ve kararları simgelemektedir (Anderson \& Dexter, 2005, s.80). Teknolojik liderlik; genel dersliklerin veya teknoloji sinıflarının 1şıklandırma sisteminden tutun da teknoloji kullanımı esnasında gerekli güvenlik önlemlerine kadar geniş bir alanı kapsamaktadır (Micheal, 1998, s.280). Ayrıca, teknolojik liderlik, bütün diğer liderlik yaklaşımlarında geçerli olan strateji ve tekniklerin bir birleşimidir. Özellikle, donanım sağlama, hızla değişen teknolojiye ayak uydurma, profesyonel gelişim ve teknoloji kullanımının sürekli geliştiğinin farkında olma gibi teknolojinin bazı özelliklerine yoğunlaşmayı gerektirmektedir (Valdez, 2004).

Çağın teknolojisini kullanabilen çağdaş insanı yetiştirmek okulların amaçları arasında yer almaktadır. Hem bireysel hem de örgütsel verimliliği artırmak için teknolojiyi okulda etkin bir biçimde bir araç olarak kullanan kişiye teknolojik lider denilmektedir. Diğer bir ifadeyle, teknolojik lider izleyenlerinin potansiyelini yönlendirirken hem kendisinin hem de izleyenlerinin teknolojiden yararlanmasını sağlayan kişidir (Can, 2003). Teknolojik lider, bilgiye ulaşacağı yerleri ve çalışanlarına 
nasıl yardım edeceğini bilen; çalışanlarından beklenilen teknolojiyi öğrenme noktasında istek gösteren; iletişime geçen ve saygıyı önemseyen kişidir (Hudanich, 2002). Teknolojik lider, örgüt amaçlarını gerçekleştirmek için dâhil olduğu yönetim süreçlerine (planlama, işbölümü, koordinasyon, eşgüdümleme, örgütleme ve değerlendirme) teknolojiyi - teknolojik araçları - bütünleştiren, bu süreçlerde teknolojiyi kullanan ve kullanımı noktasında izleyenlerine önderlik eden bireydir.

Okul liderleri, öğretmenlere teknolojinin amacının öğretmenlerin yerini almak olmadığını, öğretme ve öğrenmeyi iyileştirmek olduğunu sağlamalı (Slowinski, 2000) ve okul müdürleri teknolojik donanım ve yazılımın temininden ziyade teknolojinin eğitim ve öğretim sürecinde oynadığı role vurgu yapmalıdırlar (Creighton, 2003). Kearsley ve Lynch'e (1992) göre; iyi teknolojik liderliğin potansiyel yararları şunları içerebilir: Öğrencilerin akademik başarılarını arttırma; Öğrenci okul terklerinin ve öğrenci yıpranmasının azalması; Öğrencilerin mesleğe daha iyi hazırlanması; Daha verimli idarî operasyonlar; Öğretmen/personel mesleki tükenmişliğinin ve iş miktarının azalmasi.

Türkiye'de eğitim bilimleri ana bilim dalları tarafınca ve özellikle eğitim yönetimi disiplininde çalışılmış teknolojik liderlik konusuna ilişkin tezlerin çoğunda; bazı araştırmalarda hem yöneticilerin kendi öz hem de öğretmenlerin algılarına göre, bazı çalışmalar da ise sadece öğretmen veya yöneticilerin algılarına göre farklı kademelerdeki okul yöneticilerine ilişkin teknolojik liderlik konusunun farklı boyutlarının çözümlendiği tespit edilmiştir. Detayda ise ilk ve ortaokul öğretmenlerinin görüşlerine göre okul yöneticilerinin teknoloji liderliği (Irmak, 2015), okul müdürü ve öğretmenlerinin görüşlerine göre ilköğretim okullarında görev yapan müdürlerin teknoloji liderliği (Ölçek, 2014), bilişim teknolojisi öğretmenlerinin görüşlerine göre okul müdürlerinin teknolojik liderlik becerisi (Engür, 2014), okul müdürü görüşlerine göre ortaöğretim yöneticilerinin teknoloji liderliği öz-yeterlik algısı (Gültekin, 2013), okul müdürleri ve öğretmenlere göre bilgi toplumuna geçiş sürecinde okul yöneticilerinin teknolojik liderlik yeterliği (Görgülü, 2013) ve meslekî ve teknik öğretim okullarında görevli eğitim yöneticisi ve öğretmen görüşlerine göre mesleki ve teknik öğretim okulu yöneticilerinin teknolojik liderlik yeterlikleri (Tanzer, 2004) çalışmaları; teknolojik liderlik konusunu beceri, yeterlik ve öz-yeterlik düzeyi temelli sadece teknolojik liderlik konusunu çözümlemeyi amaçlayan çalışmalardır. Ayrıca, teknik ve endüstri meslek liselerinde görevli öğretmen görüşlerine göre teknik ve endüstri meslek lisesi yöneticilerinin teknoloji liderliği davranışları (Gürkan-Beyaz, 2014), ortaöğretim okullarında görevli öğretmen görüşlerine göre ortaöğretim okullarında görevli yöneticilerinin teknoloji liderliği rolleri (Öztaş, 2013) ve ilkokul ve ortaokulda görevli öğretmenlerin görüşlerine göre ilköğretim okulu yöneticilerinin teknoloji liderliği rolleri (Sincar, 2009) çalışmaları; sadece teknolojik liderlik konusunu rol ve davranış düzeyi temelinde çözümlemeyi amaçlayan Türkiye'de gerçekleştirilmiş çalışmalardır.

Teknolojik liderlik konusunun belirli bir boyutu ile eğitim bilimleri disiplinini ilgilendiren başka konu veya konularını birlikte çözümlemeyi amaçlamış başka çalışmaların da Türkiye'de gerçekleştirildiği tespit edilmiştir. Resmi ilkokul, ortaokul, liselerde görev yapan öğretmen görüşlerine göre okul yöneticilerinin teknolojik liderlik yeterlikleri ile öğretmenlerin teknolojik pedagojik bilgi düzeyleri arasındaki ilişki (Demirsoy, 2016), genel ve meslek liselerinde okul yöneticisi ve öğretmen görüşlerine 
göre okul yöneticilerinin teknolojik liderlik davranışları ve bilişim teknolojilerinin yönetim süreçlerinde kullanımı arasındaki ilişki (Cantürk, 2016), örgün ve yaygın eğitim örgütlerinde çalışan örgüt yöneticilerinin görüşlerine göre okul yöneticilerinin teknoloji liderliği öz-yeterlikleri ile eğitim öğretim işlerini gerçekleştirme düzeyleri arasındaki ilişki (Ulukaya, 2015), ilköğretim okullarında görev yapan öğretmenlerin görüşlerine göre yöneticilerin teknoloji liderlik düzeyi ile yönetici etkililiği arasındaki ilişki (Ertuğrul, 2014), ilköğretim okullarında çalışan yöneticiler ve öğretmenlerin görüsslerine göre eğitim yöneticilerinin teknoloji liderliği yeterlik ile öğretmenlerin teknolojiye yönelik tutumları arasındaki ilişki (Hayytov, 2013), ilköğretim okullarında görev yapan öğretmenlerin görüşlerine göre ilköğretim okulu yöneticilerinin teknoloji liderliği rolleriyle okul iklimi arasındaki ilişki (Baş, 2012), ilköğretim okulunda görev yapan yönetici ve öğretmen görüşlerine göre okul yöneticilerinin teknoloji liderliği rolleri ile bilgisayar kaygı düzeyleri arasındaki ilişki (Balaban-Uysal, 2012) ve ilköğretim ve ortaöğretim okulunda görev yapan okul müdürü ve müdür yardımcılarının görüşlerine göre ortaöğretim okul yöneticilerinin teknolojik yeterlikleri ile bilgi teknolojilerinin etkin kullanımı arasındaki ilişki (Ergişi, 2005) çalışmaları; teknolojik liderlik konusunun yeterlik, öz-yeterlik, davranış, liderlik düzeyi ve rol boyutları ile öğretmenlerin teknolojik pedagojik bilgi, bilişim teknolojilerinin yönetim süreçlerinde kullanımı, eğitim öğretim işlerini gerçekleştirme, yönetici etkililiği, teknolojiye yönelik tutumlar, okul iklimi, bilgisayar kaygısı ve bilgi teknolojilerinin etkin kullanımı konularını aralarındaki ilişki temelli çözümlemeyi amaçlayan çalışmalardır.

Yukarıda yer verilen araştırmalardan anlaşılabileceği gibi, teknolojik liderlik konusunun farklı boyutlarına ilişkin literatürde çalışmalar gerçekleştirilmiştir. Bu çalışmalar içerisinde, teknolojik liderlik konusunun, Amerika merkezli International Society for Technology in Education (ISTE) örgütünce oluşturulan National Educational Technology Standards for Administrators (NETS-A) standartları temelinde çözümlenmesi öne çıkmıştır. Bu boyutların dişında örgüte uygun güncel teknolojik liderlik çerçevesinin geliştirilmesi durumu da mevcuttur. Özellikle literatürdeki bilgi birikimine dayalı olarak öğretmen görüşlerine göre; motivasyon, yönlendirme, altyap1 ve hukuk boyutlarından oluşan yeni güncel bir ölçme aracı ile teknolojik liderlik konusuna yeni bir uygulamalı çözümleme yaklaşımı getirme ihtiyacı tespit edilmiştir.

Öğretmenlerin teknoloji kullanımı sürecinde; öğretmenlerin olası endişelerinin giderilmesi, öğretmenlerde açı beklentilerin oluşturulması, öğretmenlerin alması gereken güvenlik önlemleri, öğretmenlerce teknolojik gereçlere eşit erişimin sağlanması, öğretmenlerin okulda teknoloji kullanması noktasında motive edilmesi ve bu gereçlerin gereksiz kullanımının giderilmesi konularında öğretmenleri motive edici davranışlarının okul müdürünce sergilenme düzeyi "motivasyon” boyutu ile ölçülebilir. Öğretmenlerin teknoloji kullanımına ilişkin; konunun öneminin benimsenmesi, öğretim sürecine uygulanmasının sağlanması ve okul çevresi ile iletişime geçme noktasında teknolojik araçların kullanımının desteklenmesi meselelerinde öğretmenleri yönlendirici davranışların okul müdürlerince sergilenme düzeyi "yönlendirme" boyutu ile ölçülebilir. Öğretmenlerin teknoloji kullanımı sürecinde gerekli bilgi teknolojileri araçlarının kullanıma hazır olması, yazılım, donanım ve donanım yükseltmelerinin sağlanması gibi altyapı ihtiyaçlarının giderilmesine yönelik davranışların okul müdürlerince sergilenme düzeyi "altyapı" boyutu ile ölçülebilir. Ayrıca, öğretmenlerin teknoloji kullanımının hukuki meselelerine ilişkin; teknoloji kullanımı ile ilgili yasal 
konuların farkında olunması, kullanılan yazılımların lisanslı olması ve bu yazılımların yasadışı olarak kopyalanmasını önleyici tedbirlerin alınması, bilgisayarların etik değerlere uygun olarak kullanımı ve bilişim temelli suçları önlemeye yönelik tedbirlerin alınmasına yönelik liderlik davranışlarının okul müdürlerince sergilenme düzeyi "hukuk" boyutu ile ölçülebilir.

Milli Eğitim Bakanlığı (MEB) merkez ve taşra teşkilatında yer alan örgütlerde masaüstü ve web-tabanlı yazılımlar gibi çeşitli teknolojiler eğitim öğretim süreçleri, insan kaynağına (öğretmen, okul yöneticisi, ilçe yöneticileri vb.) ilişkin veri tabanı oluşturma ve bilgi yönetim süreçlerinde ve öğrenci bilgi yönetiminde kullanılan temel çağdaş teknolojiler arasındadır. $\mathrm{Bu}$ yazılım teknolojilerinin sürekli olarak güncellenmesi, ă̆ altyapısı ve bilgisayarların yenilenmesi MEB'in gerçekleştirdiği temel standart faaliyetler arasında yerini almıştır. Bu bağlamda, literatürde verimli ve doğru politikaların oluşturulabilmesinde, okullarda öğretmenlerin bu teknolojileri kullanımı süreçlerine önderlik eden okul müdürlerinin teknolojik liderlik davranışlarının çözümlenmesi gerekliliği literatürde mevcuttur. $\mathrm{Bu}$ motivasyon bağlamında, bu çalışmada; 2017-2018 eğitim öğretim yılı bahar döneminde Ankara Mamak İlçesindeki ortaokullarda çalışan öğretmenlerin görüşlerine göre; öğretmenlerin teknoloji kullanımında okul müdürlerinin sergilediği motivasyon, yönlendirme, altyapı, hukuk ve teknolojik liderlik davranışları toplamının düzeylerini tespit etmek amaçlanmıştır. Bu düzeylerde, öğretmenlerin cinsiyet, yaş, mesleki kıdem, öğrenim durumu, okuldaki görev süresi ve okul müdürüyle çalışma süresi değişkenleri alt grupları arasında istatistiki açıdan anlamlı farklılık olup olmadığını da tespit etmek amaçlanmıştır.

\section{Yöntem}

$\mathrm{Bu}$ araştırma, nicel yöntem olan betimsel tarama modelinde gerçekleştirilmiştir. The Office of Research Integrity'e [ORI] (2018) göre; insanı merkeze alan ve bir tür deneysel olmayan araştırma türü olan betimsel bir araştırmada; doğal olarak gerçekleşen insanın bir durumu hakkında bilgi sağlanır. Erkuş’a (2005) göre; betimsel modelde, olgular, gerçekler ve durumlar doğal biçimiyle detaylı olarak çözümlenir. Karasar'a (2009) göre; tarama modeli türü, durumun var olduğu biçimiyle tespit edildiği bir modeldir.

Şekil 1. Çalışma Modelinin Kavramsal Çerçevesi

\begin{tabular}{|c|c|}
\hline $\begin{array}{l}\text { Okul Müdürlerinin Sergilediği Teknolojik } \\
\text { Liderlik Davranışı }\end{array}$ & Değişkenler \\
\hline $\begin{array}{l}\text { a) Motivasyon } \\
\text { b) Yönlendirme } \\
\text { c) Altyapı } \\
\text { d) Hukuk }\end{array}$ & $\begin{array}{l}\text { a) Cinsiyet } \\
\text { b) Yaş } \\
\text { c) Mesleki kıdem } \\
\text { d) Eğitim durumu } \\
\text { e) Okuldaki görev süresi } \\
\text { f) Okul müdürüyle çalışma süresi }\end{array}$ \\
\hline
\end{tabular}

Şekil 1'den de anlaşılabileceği gibi, bu çalışmada; 2017-2018 eğitim öğretim y1lı bahar döneminde Ankara Mamak İlçesindeki ortaokullarda çalışan öğretmenlerin 
görüşlerine göre; öğretmenlerin teknoloji kullanımında okul müdürlerinin sergilediği motivasyon, yönlendirme, altyapı, hukuk ve teknolojik liderlik davranışları toplamının düzeyleri tespit edilmiştir. Bu düzeylerde, öğretmenlerin cinsiyet, yaş, mesleki kıdem, öğrenim durumu, okuldaki görev süresi ve okul müdürüyle çalışma süresi değişkenleri alt grupları arasında istatistiki açıdan anlamlı farklılık olup olmadı̆̆ını tespit etme temelinde istatistiki açıdan çözümlenmiştir. Teknolojik liderlik konusunun belirli değişkenler temelinde çözümlenmesinde sayısal verilerden yararlanıldığı için tarama modelinde betimsel nicel yöntem kullanılmıştır.

\section{Çalışma Grubu}

2017-2018 eğitim öğretim y1lı bahar döneminde, Ankara İli Mamak ilçesine bağlı ortaokullarda görevli 442 öğretmen araştırmanın çalışma grubunu oluşturmuştur. Çalışma grubunu oluşturan öğretmenler gönüllülük esasına göre seçilmiştir. Çalışmaya katılan öğretmenlerin teknolojiyi kullandıkları ve okul müdürlerinin teknoloji liderlik davranış1 gösterdikleri varsayılmıştır. Ayrıca çalışma 2017-2018 eğitim-öğretim yılı bahar dönemi Ankara Mamak ortaokulları verileri ve durumları ile Ankara İli Mamak İlçe Milli Eğitim Müdürlüğüne bağlı ortaokullarda görev yapan öğretmenler ile sınırlıdır. Çalışma grubunun demografik özellikleri Tablo 1'de detaylı bir biçimde aktarılmıştır.

Tablo 1

Çalışma Grubunun Demografik Özellikleri

\begin{tabular}{|c|c|c|c|}
\hline Değişken & Değişken Alt Grup & $f$ & $\%$ \\
\hline \multirow{2}{*}{ Cinsiyet } & Kadın & 266 & 60.2 \\
\hline & Erkek & 166 & 39.8 \\
\hline \multirow{4}{*}{ Yaş } & $20-30$ & 86 & 19.5 \\
\hline & $31-40$ & 199 & 45.0 \\
\hline & $41-50$ & 104 & 23.5 \\
\hline & 51 ve üzeri & 53 & 12.0 \\
\hline \multirow{5}{*}{ Mesleki kıdem } & $0-5$ y1l & 87 & 19.7 \\
\hline & $6-10 \mathrm{y} 1 \mathrm{l}$ & 89 & 20.1 \\
\hline & $11-15$ y1l & 96 & 21.7 \\
\hline & $16-20$ y1l & 86 & 19.5 \\
\hline & 21 yıl ve üzeri & 84 & 19.0 \\
\hline \multirow{2}{*}{ Öğrenim durumu } & Lisans & 398 & 90.0 \\
\hline & Lisansüstü & 44 & 10.0 \\
\hline \multirow{5}{*}{ Okuldaki görev süresi } & $0-5$ y1l & 343 & 77.6 \\
\hline & $6-10 \mathrm{y} 1 \mathrm{l}$ & 74 & 16.7 \\
\hline & $11-15$ y1l & 14 & 3.2 \\
\hline & $16-20$ y1l & 11 & 2.5 \\
\hline & 21 y1l ve üzeri & - & - \\
\hline
\end{tabular}


$0-5$ yil

$6-10$ y1l

$16-20$ y1l

21 yıl ve üzeri

Müdürle çalı̧̧ma süresi $\quad$ 11-15 yıl

91.2

$39 \quad 8.8$

Not: Çalışma grubunu oluşturan toplam ögretmen sayısl $=442$

Tablo 1 incelendiğinde, cinsiyet değişkeni açısından çalışma grubunu oluşturan öğretmenlerin \%60.2'si kadın $(f=266), \% 39.8$ 'i ise erkek öğretmenlerden $(f=166)$ oluşmuştur. Yaş açısından öğretmenlerin $(f=199)$, \%45'i 31-40 yaş aralığındadır. Mesleki kıdem açısından ise bu değişkenin alt grupları arasında birbirine oldukça yakın bir dağılım söz konusudur. Öğrenim durumu değişkeni açısından ise öğretmenlerin $(f=398)$ \%90’1 lisans diplomasına sahiptir. Okuldaki görev süresi açısından öğretmenlerin yarıdan fazlası $(f=343) \% 77.6$ 'sı 0-5 y1l arasını seçerken 21 yıl ve üzeri seçeneği hiç belirtilmemiştir. Bu okuldaki okul müdürüyle çalışma süresi açısından öğretmenler sadece iki seçeneği işaretlemiştir; öğretmenlerden ( $f=403) \% 91.2$ 'si 0-5 y1l arasını seçerken geriye kalanları $(f=39)$ \%8.8'i 6-10 yıl aralığını işaretlemiştir. 11-15 y1l, 16-20 yıl ve 21 yıl ve üzeri seçenekleri hiç belirtilmemiştir.

\section{Veri Toplama Aracı}

$\mathrm{Bu}$ çalışmada, bir adet nicel ölçme aracı kullanılarak öğretmen görüşleri alınmıştır. Bu araç, Durnalı'nın (2018) geliştirdiği “Okul Müdürü Teknolojik Liderlik Davranış Ölçeği (OMTLD-Ö)"'dir. OMTLD-Ö’ün özelliklerine aşağıda detaylı olarak yer verilmiştir.

Okul Müdürü Teknolojik Liderlik Davranış Ölçeği (OMTLD-Ö). Durnalı (2018) tarafınca geliştirilen Okul Müdürü Teknolojik Liderlik Davranış Ölçeği (OMTLD-Ö), motivasyon, yönlendirme, altyapı ve hukuk olmak üzere dört alt boyutlu olup, 18 maddeden oluşmaktadır. OMTLD-Ö, ortaokullarda görevli öğretmenlerin görüşlerine göre, okulda öğretmenlerin teknoloji kullanımında okul müdürlerinin sergilediği teknolojik liderlik davranışlarını çözümlemek amacıyla geliştirilmiştir. Ölçeğin dört alt boyutlu yapısına ilişkin Cronbach Alfa güvenirlik katsayısı .72 bulunmuş ikenmotivasyon alt boyutunda .90 , yönlendirme alt boyutunda .88 , altyapı alt boyutunda .87 ve hukuk alt boyutunda .70 olarak tespit edilmiştir. OMTLD-Ö, "Kesinlikle katılmıyorum; Katılmıyorum; Kararsızım; Katılıyorum; Kesinlikle katılıyorum" seçeneklerinin yer aldığı beşli Likert tipinde bir ölçektir. Ölçekten elde edilen puanın yüksek olması durumunda ilgili davranışların okul müdürlerince yüksek düzeyde sergilendiği; düşük olması durumunda ise ilgili davranışların okul müdürlerince düşük düzeyde sergilendiği ifade edilebilir.

\section{Veri Toplama Süreci}

Hacettepe Üniversitesi Senatosu Etik Komisyonundan etik onay ve Ankara İl Milli Eğitim Müdürlüğü Strateji Geliştirme Şube Müdürlüğü Araştırma İzinleri Komisyonundan ölçek uygulama (veri toplama) izni alınmıştır. 212 öğretmenden Google form aracı ile İnternet üzerinden ve 230 öğretmenden kâğıt formlar aracılığıyla veri toplanmıştır. 


\section{Verilerin Analizi}

Verilerin analizinde; aritmetik ortalama, frekans ve standart sapma gibi betimsel istatistik yöntemleri ve t-testi gibi sonuç ve anlam sağlayıcı istatistik yöntemleri kullanılmıştır. Parametrik ve non-parametrik test koşulları temelinde çalışmanın amaçlarına ilişkin ölçekten elde edilen veri geneli ve veri alt gruplarının normallik ve varyans eşitliği testleri her bir amaç için ayrı olarak gerçekleştirilmiştir. p değeri 0.05 (\%5)'ten küçük ise analiz bulgusunda anlamlı bir fark olduğu sonucu elde edilmiştir.

OMTLD-Ö puanlarının aritmetik ortalamasının derecelendirme düzeylerine Tablo 2'de yer verilmiştir. Bulgular bölümünde tablo altı aritmetik ortalama değerleri yorumlanırken bu katılım düzeyi aralıkları dikkate alınmıştır.

Tablo 2

OMTLD-Ö Seçeneklerine Karşılık Gelen Puan Aralıkları

\begin{tabular}{lcc}
\hline Derece & Seçenekler & Puan Aralıkları \\
\hline 1 & Kesinlikle Katılmıyorum & $1.00-1.80$ \\
2 & Katılmıyorum & $1.81-2.60$ \\
3 & Kararsızım & $2.61-3.40$ \\
4 & Katıliyorum & $3.41-4.20$ \\
5 & Kesinlikle Katıliyorum & $4.21-5.00$ \\
\hline
\end{tabular}

Parametrik test tekniklerini kullanabilmek için birey, ölçek ve veriler şu koşulları sağlamalıdır:

1. Ölçek, aralıklı ya da oranlı tipte olmalıdır.

2. Ölçülecek konu geneli ve alt gruplarında veri normal dağılmalıdır.

3. Ölçülecek konu geneli ve alt gruplarında varyans homojen (eşit) dağılmalıdır (Altunışık, Coşkun, Bayraktaroğlu, \& Yıldırım, 2010; Field, 2009).

Araştırmada kullanılan ölçek birinci koşulu sağlamıştır. Ayrıca, farklı veri setleri geneli ve boyutları, değişkenlerin alt gruplarına karşılık gelen verilerin analizi, gerçekleştirilen normallik varsayım bulguları incelenmiş ve ikinci koşul da sınanmıştır. Veri gruplarına ilişkin Levene testi ile varyans homojenliği test edilerek üçüncü koşul da test edilmiştir. Özetle, parametrik ve non-parametrik test koşulları temelinde çalışmanın amaçlarına ilişkin ölçeklerden elde edilen genel veri ve veri alt gruplarının normallik testleri her bir amaç için ayrı olarak gerçekleştirilmiş ve elde edilen bulgular doğrultusunda parametrik veya non-parametrik teknikler kullanılarak çalışmanın amaçları çözümlenmiştir.

\section{Bulgular}

$\mathrm{Bu}$ k1sımda öncelikle; öğretmenlerin görüşlerine göre; öğretmenlerin teknoloji kullanımında okul müdürlerinin sergilediği motivasyon, yönlendirme, altyapı, hukuk ve teknolojik liderlik davranışları toplamı düzeylerine ilişkin bulgular ve yorumlara yer verilmiştir. Bu düzeylere ilişkin öğretmen görüşlerinin cinsiyet, yaş, mesleki kıdem, eğitim durumu, okuldaki görev süresi ve okul müdürüyle çalışma süresi değişkenlerine göre istatistiki açıdan anlamlı farklılık durumuna ilişkin bulgular ve yorumlara yer verilmiştir. 


\section{Öğretmenlere Göre Okul Müdürlerinin Teknolojik Liderlik Davranışları}

$\mathrm{Bu}$ kısımda; öğretmenlerin görüşlerine göre; öğretmenlerin teknoloji kullanımında okul müdürlerinin sergilediği motivasyon, yönlendirme, altyapı, hukuk ve teknolojik liderlik davranışları toplamı düzeylerine ilişkin bulgular ve yorumlara yer verilecektir.

Tablo 3

Öğretmenlerin Görüşlerine Göre Öğretmenlerin Teknoloji Kullanımında Okul Müdürlerinin Sergilediği Teknolojik Liderlik Davranış Düzeyleri

\begin{tabular}{|c|c|c|c|c|c|c|}
\hline & OMTLD-Ö & $\bar{X}$ & $S$ & Min. & Max. & Düzey \\
\hline \multirow{4}{*}{ 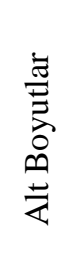 } & Motivasyon & 3.57 & 0.81 & 1.00 & 5.00 & Katıliyorum \\
\hline & Yönlendirme & 3.67 & 0.79 & 1.33 & 5.00 & Katıliyorum \\
\hline & Altyapı & 3.73 & 0.78 & 1.75 & 5.00 & Katıliyorum \\
\hline & Hukuk & 3.72 & 0.69 & 1.60 & 5.00 & Katıliyorum \\
\hline \multicolumn{2}{|c|}{$\begin{array}{c}\text { Teknolojik Liderlik Davranışlar } \\
\text { Toplamı }\end{array}$} & 3.67 & 0.58 & 2.17 & 5.00 & Katıliyorum \\
\hline
\end{tabular}

Tablo 3'te yer verildiği gibi, öğretmenlerin görüşlerine göre; öğretmenlerin teknoloji kullanımında okul müdürlerinin sergilediği teknolojik liderlik davranış genel ortalama puanı $(\bar{X}=3.67)$ 'dir ve bu durum öğretmen görüşlerinin "Katılıyorum (3.414.20)" düzeyinde olduğuna işaret etmektedir. Benzer biçimde, alt boyutların tümünde de öğretmenlerin görüşleri "Katılıyorum (3.41-4.20)" düzeyi aralığındadır. Teknolojik liderlik davranışları bütününde ve boyutlarında puan ortalamaları birbirine yakın çıkmıştır denilebilir. En yüksek ortalama puan, altyapı boyutunda çıkmıştır. Öğretmen görüşlerine göre; öğretmenlerin okulda teknoloji kullanımında, okul müdürlerinin sergilediği teknolojik liderlik davranışları düzeylerinin dört alt boyutunun ve teknolojik liderlik davranışları bütününün katılıyorum düzeyinde gerçekleştiği ifade edilebilir. Ortalama puanlara göre, ortalaması yüksekten alçağa doğru boyutlar şu şekilde sıralanmıştır: altyapı, hukuk, yönlendirme ve motivasyon. Bu kapsamda araştırmaya katılan öğretmenler; kendilerinin okulda teknoloji kullanımında, okul müdürlerinin sergilediği teknolojik liderlik davranışları düzeylerinin yeterli olduğu görüşüne sahip oldukları söylenebilir. Başka bir deyişle, bu araştırmaya konu olan okul müdürlerinin teknolojik liderlik davranışlarını genellikle sergiledikleri söylenebilir.

2017-2018 eğitim öğretim yılı bahar döneminde Ankara Mamak İlçesindeki ortaokullarda, öğretmenlerin teknoloji kullanımı sürecinde okul müdürlerinin öğretmenlere çoğunlukla yardımcı oldukları, onları motive ettikleri ve yönlendirdikleri şeklinde bir çıkarıma varılabilir. Öğretmenlerin teknoloji kullanımı süreçlerinde hukuki ve teknolojik altyapı meseleleri açılarından çok fazla sorun yaşanmadığına ilişkin bir sonuca da varılabilir. Bu durum, detaylı olarak şu biçimde açıklanabilir. Bu okullarda, öğretmenlerin teknoloji kullanımına ilişkin; öğretmenlerin olası endişelerinin giderilmesi, öğretmenlerde açı beklentilerin oluşturulması, öğretmenlerin alması gereken güvenlik önlemleri, öğretmenlerce teknolojik gereçlere eşit erişimin sağlanması 
ve bu gereçlerin gereksiz kullanımının giderilmesi konularında öğretmenleri motive edici davranışların okul müdürlerince çoğunlukla sergilendiği ifade edilebilir.

$\mathrm{Bu}$ okullarda, öğretmenlerin teknoloji kullanımına ilişkin; konunun öneminin benimsenmesi, öğretim sürecine uygulanmasının sağlanması ve okul çevresi ile iletişime geçme noktasında teknolojik araçların kullanımının desteklenmesi meselelerinde öğretmenleri yönlendirici davranışların okul müdürlerince çoğunlukla sergilendiği ifade edilebilir. Bu okullarda, öğretmenlerin teknoloji kullanımı sürecinde gerekli bilgi teknolojileri araçlarının kullanıma hazır olması, yazılım, donanım ve donanım yükseltmelerinin sağlanması gibi altyapı ihtiyaçlarının giderilmesine yönelik davranışların okul müdürlerince çoğunlukla gerçekleştirildiği de ifade edilebilir. Ayrıca, öğretmenlerin teknoloji kullanımının hukuki meselelerine ilişkin; teknoloji kullanımı ile ilgili yasal konuların farkında olunması, kullanılan yazılımların lisanslı olması ve bu yazılımların yasadışı olarak kopyalanmasını önleyici tedbirlerin alınması, bilgisayarların etik değerlere uygun olarak kullanımı ve bilişim temelli suçları önlemeye yönelik tedbirlerin alınmasına yönelik liderlik davranışlarının okul müdürlerince çoğunlukla sergilendiği ifade edilebilir.

\section{Öğretmenlerin Cinsiyetlerine Göre Okul Müdürlerinin Teknolojik Liderlik Davranışları}

$\mathrm{Bu}$ kısımda, cinsiyet değişkeni bağlamında öğretmenlerin görüşlerine göre öğretmenlerin teknoloji kullanımında okul müdürlerinin sergilediği motivasyon, yönlendirme, altyapı, hukuk ve teknolojik liderlik davranışları toplamı düzeylerine ilişkin bulgular ve yorumlara yer verilecektir.

Tablo 4

Cinsiyet Değişkenine Göre OMTLD-Ö Toplamına Illişkin Öğretmen Görüşlerinin Aritmetik Ortalama $(\bar{X})$, Standart Sapma $(S)$, t-test'i Değerleri

\begin{tabular}{lcccccc}
\hline Cinsiyet & $n$ & $\bar{X}$ & $S$ & $t$ & $p$ & Fark \\
\hline Kadın & 266 & 3.68 & 0.59 & & & \\
Erkek & 176 & 3.65 & 0.56 & .50 & .62 & - \\
Toplam & 442 & 3.67 & 0.58 & & & \\
\hline
\end{tabular}

Tablo 4'ten anlaş1labileceği üzere, çalışma grubunun, öğretmenlerin teknoloji kullanımında okul müdürlerinin sergilediği teknolojik liderlik davranışları ortalama puanı temelinde, kadın ve erkek öğretmenlerin görüşleri arasında istatistiki açıdan anlamlı bir farklılık tespit edilmemiştir $(p>0.05)$. Kadın öğretmenlerin görüşlerinin ortalama puanı $(\bar{X}=3.68)$ 'dir. Erkek öğretmenlerin görüşleri ortalama puanı, $(\bar{X}=3.65)$ 'dir. $\mathrm{Bu}$ durum, kadın ve erkek öğretmen görüşlerinin 'Katıllyorum (3.414.20)" düzeyinde olduğuna işaret etmektedir. Kadın ve erkek öğretmenlere göre; öğretmenlerin okulda teknoloji kullanımında, okul müdürlerinin sergilediği teknolojik liderlik davranışları toplamının katılıyorum düzeyinde gerçekleștiği ifade edilebilir. Kadın ve erkek öğretmenlerin okul müdürlerinin sergilediği teknolojik liderlik davranışları toplamına ilişkin görüşleri birbirlerine çok benzemektedir denilebilir. 
Tablo 5

Cinsiyet Değişkenine Göre OMTLD-Ö Boyutlarına İlişkin Öğretmen Görüşlerinin Aritmetik Ortalama $(\bar{X})$, Standart Sapma (S), Mann Whitney U Testi Değerleri

\begin{tabular}{|c|c|c|c|c|c|c|c|c|}
\hline $\begin{array}{l}\text { OMTLD-Ö Alt } \\
\text { Boyutlar }\end{array}$ & Cinsiyet & $n$ & $\bar{X}$ & $S$ & Sira Ort. & $U$ & $p$ & Fark \\
\hline & Kadın & 266 & 3.58 & 0.81 & 222.45 & & & \\
\hline \multirow[t]{3}{*}{ Motivasyon } & Erkek & 176 & 3.56 & 0.82 & 220.06 & 23155.00 & 0.85 & - \\
\hline & Toplam & 442 & 3.57 & 0.81 & & & & \\
\hline & Kadın & 266 & 3.68 & 0.82 & 223.78 & & & \\
\hline \multirow[t]{3}{*}{ Yönlendirme } & Erkek & 176 & 3.66 & 0.76 & 218.05 & 22801.50 & 0.64 & - \\
\hline & Toplam & 442 & 3.67 & 0.79 & & & & \\
\hline & Kadın & 266 & 3.74 & 0.79 & 223.97 & & & \\
\hline \multirow[t]{3}{*}{ Altyap1 } & Erkek & 176 & 3.71 & 0.76 & 217.77 & 22751.50 & 0.61 & - \\
\hline & Toplam & 442 & 3.73 & 0.78 & & & & \\
\hline & Kadın & 266 & 3.72 & 0.72 & 223.78 & & & \\
\hline \multirow[t]{2}{*}{ Hukuk } & Erkek & 176 & 3.72 & 0.65 & 218.06 & 22802.00 & 0.64 & - \\
\hline & Toplam & 442 & 3.72 & 0.69 & & & & \\
\hline
\end{tabular}

Tablo 5'ten anlaşılabileceği üzere, öğretmenlerin teknoloji kullanımında okul müdürlerinin sergilediği motivasyon, yönlendirme, altyapı ve hukuk davranışlarına ilişkin çalışma grubunu oluşturan öğretmen görüşlerinin ortalama puanları temelinde, kadın ve erkek görüşleri arasında istatistiki açıdan anlamlı bir farklılık tespit edilmemiştir $(p>0.05)$. Kadın öğretmenlerin görüşlerinin en yüksek olduğu ortalama puanı $(\bar{X}=3.74)$ ile altyapı boyutunda iken en düşük ise $(\bar{X}=3.58)$ ile motivasyon boyutundadır. Erkek öğretmenlerin görüşlerinin en yüksek olduğu ortalama puanı $(\bar{X}=3.72)$ ile hukuk boyutunda iken en düşük ise $(\bar{X}=3.56)$ ile motivasyon boyutundadır. Motivasyon boyutu kadın ve erkek öğretmenlerin görüşlerine ilişkin puanın en düşük olduğu boyuttur. Sonuç olarak, kadın ve erkek öğretmen görüşleri OMTLD-Ö’nün bütün boyutlarında "Katılıyorum (3.41-4.20)" aralığı düzeyinde değişmektedir. Kadın ve erkek öğretmenlere göre; öğretmenlerin okulda teknoloji kullanımında okul müdürlerinin sergilediği teknolojik liderlik davranışları alt boyutlarının katılıyorum düzeyinde gerçekleştiği ifade edilebilir. Kadın ve erkek öğretmenlerin, okul müdürlerinin bu davranış düzeylerinin dört alt boyutuna ilişkin görüşleri birbirlerine çok yakın değerde çıkmıştır denilebilir.

\section{Öğretmenlerin Yaşlarına Göre Okul Müdürlerinin Teknolojik Liderlik Davranışları}

$\mathrm{Bu}$ kısımda, yaş değişkeni bağlamında, öğretmenlerin görüşlerine göre öğretmenlerin teknoloji kullanımında okul müdürlerinin sergilediği motivasyon, yönlendirme, altyapı, hukuk ve teknolojik liderlik davranışları toplamı düzeylerine ilişkin bulgulara ve yorumlara yer verilecektir. 
Tablo 6

Yaş Değişkenine Göre OMTLD-Ö Toplamı ve Boyutlarına Ilişkin Öğretmen

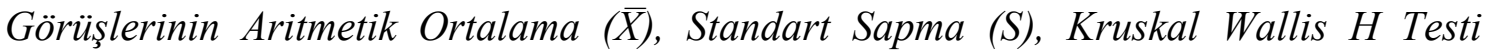
Değerleri

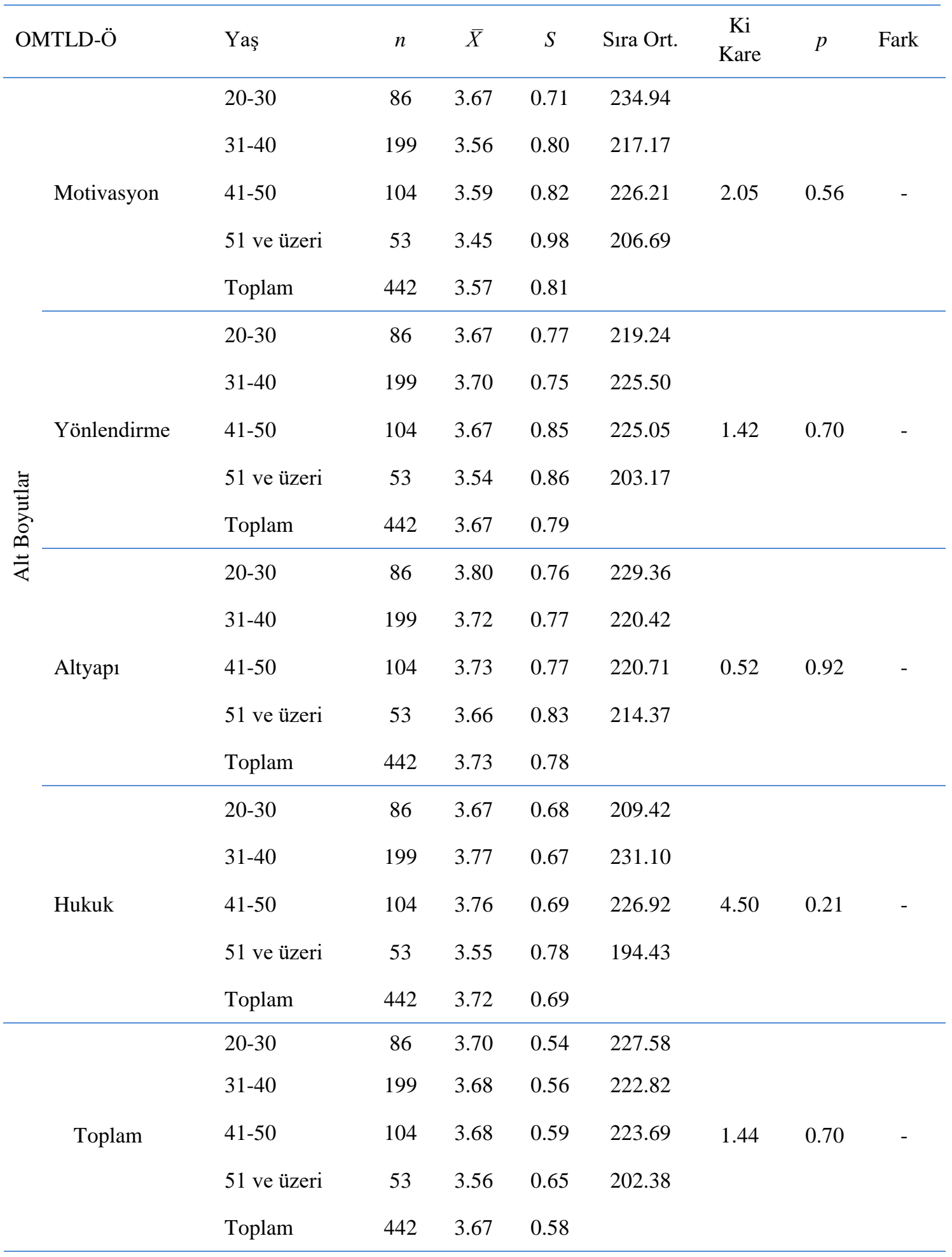

Tablo 6'dan anlaş1labileceği üzere, çalışma grubunu oluşturan öğretmenlerin teknoloji kullanımında okul müdürlerinin sergilediği teknolojik liderlik davranışları toplamı ve boyutları ortalama puanları temelinde, yaş değişkeninin alt grupları bağlamında çalışma grubunu oluşturan öğretmen görüşlerinin görüşleri arasında istatistiki açıdan anlamlı bir farklılık tespit edilmemiştir $(p>0.05)$. Bu durumda bu 
araştırmadaki çalışma grubunda nesiller arasında teknoloji kullanım ve değerlendirme noktasında dijital göçmen ve yerli gibi kavramların genellikle gözükmediğinin bir işareti olarak yorumlanabilir. Diğer bir deyişle, okul müdürlerinin teknolojik liderlik davranışlarını gözlemleme ve değerlendirme noktasında öğretmenler arası nesil ya da yaş grupları benzerlik göstermektedir. Görüşlerin en yüksek olduğu ortalama puanı $(\bar{X}=3.80)$ ile 20-30 yaş aralığı grubunda altyapı boyutunda iken, en düşük ise $(\bar{X}=3.45)$ ile motivasyon boyutunda 51 ve üzeri yaş aralığı grubundadır. Yaşları farklı öğretmenlerin teknolojik liderlik davranışları toplamı ve boyutlarına ilişkin görüşleri, "Katılıyorum (3.41-4.20)" aralığında değişmektedir. Farklı yaş gruplarındaki öğretmenlere göre; öğretmenlerin okulda teknoloji kullanımında, okul müdürlerinin sergilediği teknolojik liderlik davranışları toplamının ve dört alt boyutunun katılıyorum düzeyinde gerçekleştiği ifade edilebilir.

\section{Öğretmenlerin Mesleki Kıdemlerine Göre Okul Müdürlerinin Teknolojik Liderlik Davranışları}

$\mathrm{Bu}$ kısımda, mesleki kıdem değişkeni bağlamında, öğretmenlerin görüşlerine göre öğretmenlerin teknoloji kullanımında okul müdürlerinin sergilediği motivasyon, yönlendirme, altyapı, hukuk ve teknolojik liderlik davranışları toplamı düzeylerine ilişkin bulgulara ve yorumlara yer verilecektir.

Tablo 7

Mesleki Kıdem Değişkenine Göre OMTLD-Ö Toplamına İlişkin Öğretmen Görüşlerinin Aritmetik Ortalama $(\bar{X})$, Standart Sapma (S), Tek Yönlü Varyans Analizi (One-Way Anova) Testi Değerleri

\begin{tabular}{|c|c|c|c|c|c|c|c|}
\hline & Mesleki kıdem & $n$ & $\bar{X}$ & $S$ & $F$ & $p$ & Fark \\
\hline \multirow{6}{*}{ OMTLD-Ö Toplam } & $0-5$ y1l & 87 & 3.74 & 0.55 & \multirow{6}{*}{1.07} & \multirow{6}{*}{.37} & \multirow{6}{*}{ - } \\
\hline & $6-10$ y1l & 89 & 3.74 & 0.57 & & & \\
\hline & $11-15$ y1l & 96 & 3.61 & 0.53 & & & \\
\hline & $16-20 \mathrm{y} 1 \mathrm{l}$ & 86 & 3.61 & 0.58 & & & \\
\hline & 21 yıl ve üzeri & 84 & 3.66 & 0.64 & & & \\
\hline & Toplam & 442 & 3.67 & 0.58 & & & \\
\hline
\end{tabular}

Tablo 7'den anlaşılabileceği üzere, öğretmenlerin teknoloji kullanımında okul müdürlerinin sergilediği teknolojik liderlik davranışları toplamına ilişkin çalışma grubunu oluşturan öğretmen görüşlerinin ortalama puanının, mesleki kıdem değişkeninin alt grupları arasında istatistiki açıdan anlamlı bir farklılık göstermediği tespit edilmiştir $(p>0.05)$. Bu durumda; okul müdürlerinin teknolojik liderlik davranışlarını gözlemleme ve değerlendirme noktasında öğretmenler arası mesleki kıdemin bir etkisi yoktur yorumu yapılabilir. Görüşlerin en yüksek olduğu ortalama puanı $(\bar{X}=3.74)$ ile $0-5$ ve 6-10 yıl kıdem aralığ1 gruplarında iken en düşük ise $(\bar{X}=3.61)$ ile 11-15 ve 16-20 yıl kıdem aralığ gruplarındadır. Mesleki kıdem değişkeninin alt gruplarında OMTLD-Ö’ne ilişkin öğretmen görüşleri ortalama puanları “Katılıyorum (3.41-4.20)" aralığında değişmektedir. Farklı mesleki kıdem gruplarındaki öğretmenlere 
göre; öğretmenlerin okulda teknoloji kullanımında, okul müdürlerinin sergilediği teknolojik liderlik davranışları toplamının katılıyorum düzeyinde gerçekleştiği ifade edilebilir.

Tablo 8

Mesleki Kıdeme Göre OMTLD-Ö Boyutlarına İlişkin Öğretmen Görüşlerinin Aritmetik Ortalama $(\bar{X})$, Standart Sapma (S), Kruskal Wallis H Testi Değerleri

\begin{tabular}{|c|c|c|c|c|c|c|c|c|}
\hline OMTLD-Ö & Mesleki kıdem & $n$ & $\bar{X}$ & $S$ & $\begin{array}{l}\text { Sira } \\
\text { Ort. }\end{array}$ & $\begin{array}{c}\text { Ki } \\
\text { Kare }\end{array}$ & $p$ & Fark \\
\hline \multirow{6}{*}{ Motivasyon } & $0-5$ y1l & 87 & 3.73 & 0.74 & 245.60 & \multirow{6}{*}{6.73} & \multirow{6}{*}{0.15} & \\
\hline & $6-10 \mathrm{y} 1 \mathrm{l}$ & 89 & 3.63 & 0.84 & 230.98 & & & \\
\hline & $11-15$ y1l & 96 & 3.48 & 0.72 & 201.47 & & & \\
\hline & $16-20$ y1l & 86 & 3.46 & 0.87 & 209.58 & & & \\
\hline & 21 yıl ve üzeri & 84 & 3.57 & 0.88 & 221.59 & & & \\
\hline & Toplam & 442 & 3.57 & 0.81 & & & & \\
\hline \multirow{6}{*}{ Yönlendirme } & $0-5$ y1l & 87 & 3.67 & 0.81 & 220.33 & \multirow{6}{*}{2.36} & \multirow{6}{*}{0.67} & \multirow{6}{*}{-} \\
\hline & $6-10 \mathrm{y} 1 \mathrm{l}$ & 89 & 3.72 & 0.82 & 232.54 & & & \\
\hline & $11-15$ y1l & 96 & 3.69 & 0.66 & 221.57 & & & \\
\hline & $16-20$ yil & 86 & 3.56 & 0.81 & 205.01 & & & \\
\hline & 21 yıl ve üzeri & 84 & 3.69 & 0.87 & 227.82 & & & \\
\hline & Toplam & 442 & 3.67 & 0.79 & & & & \\
\hline \multirow{6}{*}{ Altyap1 } & $0-5$ y1l & 87 & 3.78 & 0.78 & 226.15 & \multirow{6}{*}{1.68} & \multirow{6}{*}{0.79} & \multirow{6}{*}{ - } \\
\hline & $6-10 \mathrm{y} 1 \mathrm{l}$ & 89 & 3.79 & 0.78 & 233.54 & & & \\
\hline & $11-15$ y1l & 96 & 3.70 & 0.73 & 214.77 & & & \\
\hline & $16-20$ y1l & 86 & 3.65 & 0.80 & 211.95 & & & \\
\hline & 21 yıl ve üzeri & 84 & 3.73 & 0.80 & 221.39 & & & \\
\hline & Toplam & 442 & 3.73 & 0.78 & & & & \\
\hline \multirow{6}{*}{ Hukuk } & $0-5$ y1l & 87 & 3.73 & 0.68 & 218.95 & \multirow{6}{*}{4.96} & \multirow{6}{*}{0.29} & \multirow{6}{*}{ - } \\
\hline & $6-10 \mathrm{y} 11$ & 89 & 3.80 & 0.71 & 238.74 & & & \\
\hline & $11-15$ y1l & 96 & 3.63 & 0.65 & 204.51 & & & \\
\hline & $16-20$ yıl & 86 & 3.80 & 0.64 & 235.31 & & & \\
\hline & 21 yıl ve üzeri & 84 & 3.66 & 0.76 & 211.15 & & & \\
\hline & Toplam & 442 & 3.72 & 0.69 & & & & \\
\hline
\end{tabular}

Tablo 8'den anlaşılabileceği üzere, öğretmenlerin teknoloji kullanımında okul müdürlerinin sergilediği motivasyon, yönlendirme, altyapı ve hukuk davranışlarına ilişkin çalışma grubunu oluşturan öğretmen görüşlerinin ortalama puanlarının, mesleki 
kıdem değişkeninin alt grupları arasında istatistiki açıdan anlamlı bir farklılık göstermediği tespit edilmemiştir ( $p>0.05)$. Bu durumda; okul müdürlerinin teknolojik liderlik davranışlarını gözlemleme ve değerlendirme noktasında öğretmenler arası mesleki kıdemin bir etkisi yoktur yorumu yapılabilir. Görüşlerin en yüksek olduğu ortalama puanı $(\bar{X}=3.80)$ ile hukuk alt boyutunda $6-10$ ve $16-20$ yıl yaş aralığ gruplarında iken en düşük ise $(\bar{X}=3.46)$ ile motivasyon alt boyutunda $16-20$ y1l yaş aralığ1 gruplarındadır. Mesleki kıdem değişkeninin alt gruplarında OMTLD-Ö boyutlarına ilişkin öğretmen görüşleri ortalama puanları "Katılıyorum (3.41-4.20)" aralığında değişmektedir. Farklı mesleki kıdem gruplarındaki öğretmenlere göre; öğretmenlerin okulda teknoloji kullanımında, okul müdürlerinin sergilediği teknolojik liderlik davranışları dört alt boyutunun katılıyorum düzeyinde gerçekleştiği ifade edilebilir.

\section{Öğretmenlerin Öğrenim Durumlarına Göre Okul Müdürlerinin Teknolojik Liderlik Davranışları}

$\mathrm{Bu}$ kısımda, öğrenim durumu değişkeni bağlamında, öğretmenlerin görüşlerine göre öğretmenlerin teknoloji kullanımında okul müdürlerinin sergilediği motivasyon, yönlendirme, altyapı, hukuk ve teknolojik liderlik davranışları toplamı düzeylerine ilişkin bulgulara ve yorumlara yer verilecektir.

Tablo 9

Öğrenim Durumu Değişkenine Göre OMTLD-Ö Toplamına İlişkin Öğretmen Görüşlerinin Aritmetik Ortalama $(\bar{X})$, Standart Sapma (S), T-Testi Değerleri

\begin{tabular}{lcccccc}
\hline Öğrenim Durumu & $n$ & $\bar{X}$ & $S$ & $t$ & $p$ & Fark \\
\hline Lisans & 398 & 3.68 & 0.57 & & & \\
Lisansüstü & 44 & 3.63 & 0.65 & 0.51 & 0.61 & - \\
Toplam & 442 & 3.67 & 0.58 & & & \\
\hline
\end{tabular}

Tablo 9'dan anlaşılabileceği üzere, öğretmenlerin teknoloji kullanımında okul müdürlerinin sergilediği teknolojik liderlik davranışlarına ilişkin çalışma grubunu oluşturan öğretmenlerin görüşlerinin ortalama puanı temelinde, lisans ve lisansüstü eğitimi görmüş öğretmenlerin görüşleri arasında istatistiki açıdan anlamlı bir farklılık tespit edilmemiştir $(p>0.05)$. Lisans eğitimi görmüş öğretmen görüşlerinin ortalama puanı ( $\bar{X}=3.68)$ 'dir ve lisansüstü eğitimi görmüş öğretmen görüşlerinin ortalama puanı $(\bar{X}=3.63)$ 'dür. $\mathrm{Bu}$ durum, lisans ve lisansüstü eğitimi görmüş öğretmen görüşlerinin "Katılıyorum (3.41-4.20)" düzeyinde olduğuna işaret etmektedir. Lisans ve lisansüstü eğitim görmüş öğretmenlere göre; öğretmenlerin okulda teknoloji kullanımında, okul müdürlerinin sergilediği teknolojik liderlik davranışları toplamının katılıyorum düzeyinde gerçekleştiği ifade edilebilir. Lisans ve lisansüstü eğitim görmüş öğretmenlerin okul müdürlerinin bu davranış düzeylerini gerçekleştirmelerine ilişkin görüşleri birbirlerine çok benzemektedir denilebilir.

Tablo 10'dan anlaşılabileceği üzere, öğretmenlerin teknoloji kullanımında okul müdürlerinin sergilediği motivasyon, yönlendirme, altyapı ve hukuk davranışlarına ilişkin çalışma grubunu oluşturan öğretmen görüşlerinin ortalama puanları temelinde, 
lisans ve lisansüstü eğitimi almış öğretmenlerin görüşleri arasında istatistiki açıdan anlamlı bir farklılık tespit edilmemiştir $(p>0.05)$. Lisans eğitimi almış öğretmenlerin görüşlerinin en yüksek olduğu ortalama puanı $(\overline{\mathrm{X}}=3.74)$ ile altyapı boyutunda iken, en düşük ise $(\bar{X}=3.58)$ ile motivasyon boyutundadır. Lisansüstü eğitimi almış öğretmenlerin görüşlerinin en yüksek olduğu ortalama puanı $(\bar{X}=3.72)$ ile hukuk boyutunda iken, en düşük ise $(\bar{X}=3.51)$ ile motivasyon boyutundadır. Motivasyon boyutu, lisans ve lisansüstü eğitimi almış öğretmenlerin görüşlerine ilişkin puanın en düşük olduğu boyuttur. Sonuç olarak, lisans ve lisansüstü eğitimi almış öğretmen görüşleri bütün boyutlarda "Katılıyorum (3.41-4.20)" aralığı düzeyinde değişmektedir. Lisans ve lisansüstü eğitim görmüş öğretmenlere göre; öğretmenlerin okulda teknoloji kullanımında, okul müdürlerinin sergilediği teknolojik liderlik davranışları dört alt boyutunun katılıyorum düzeyinde gerçekleştiği ifade edilebilir. Lisans ve lisansüstü eğitim görmüş öğretmenlerin okul müdürlerinin bu davranış düzeylerini gerçekleştirmelerine ilişkin görüşleri bütün boyutlarda birbirlerine çok yakın değerde çıkmıştır denilebilir.

Tablo 10

Öğrenim Durumu Değişkenine Göre OMTLD-Ö Boyutlarına İlişkin Öğretmen

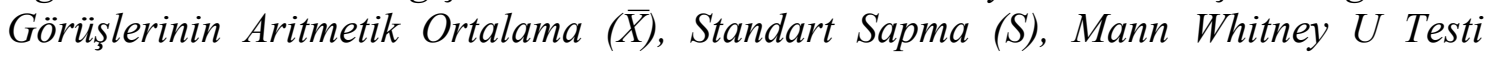
Değerleri

\begin{tabular}{ccccccccc}
\hline OMTLD-Ö & Öğrenim & $n$ & $\bar{X}$ & $S$ & Sira Ort. & $U$ & $p$ & Fark \\
Alt Boyutlar & Durumu & & & & & & & \\
\hline \multirow{3}{*}{ Motivasyon } & Lisans & 398 & 3.58 & 0.81 & 221.86 & & & \\
& Lisansüstü & 44 & 3.51 & 0.84 & 218.22 & 8611.50 & 0.86 & - \\
& Toplam & 442 & 3.57 & 0.81 & & & & \\
\hline \multirow{3}{*}{ Yönlendirme } & Lisans & 398 & 3.66 & 0.80 & 220.68 & & & \\
& Lisansüstü & 44 & 3.71 & 0.73 & 228.91 & 8430.00 & 0.68 & - \\
& Toplam & 442 & 3.67 & 0.79 & & & & \\
\hline \multirow{3}{*}{ Altyap1 } & Lisans & 398 & 3.74 & 0.74 & 221.40 & & & \\
& Lisansüstü & 44 & 3.63 & 1.05 & 222.36 & 8718.00 & 0.96 & - \\
& Toplam & 442 & 3.73 & 0.78 & & & & \\
\hline \multirow{2}{*}{ Hukuk } & Lisans & 398 & 3.72 & 0.69 & 221.00 & & & \\
& Lisansüstü & 44 & 3.72 & 0.73 & 225.99 & 8558.50 & 0.81 & - \\
& Toplam & 442 & 3.72 & 0.69 & & & & \\
\hline
\end{tabular}

\section{Öğretmenlerin Görev Sürelerine Göre Okul Müdürlerinin Teknolojik}

\section{Liderlik Davranışları}

$\mathrm{Bu}$ kısımda, okuldaki görev süresi değişkeni bağlamında, öğretmenlerin görüşlerine göre öğretmenlerin teknoloji kullanımında okul müdürlerinin sergilediği motivasyon, yönlendirme, altyapı, hukuk ve teknolojik liderlik davranışları toplamı düzeylerine ilişkin bulgulara ve yorumlara yer verilecektir. 
Tablo 11

Okuldaki Görev Süresi Değişkenine Göre OMTLD-Ö Toplamı ve Boyutlarına İlişkin Ögretmen Görüşlerinin Aritmetik Ortalama $(\bar{X})$, Standart Sapma (S), Kruskal Wallis H Testi Değerleri

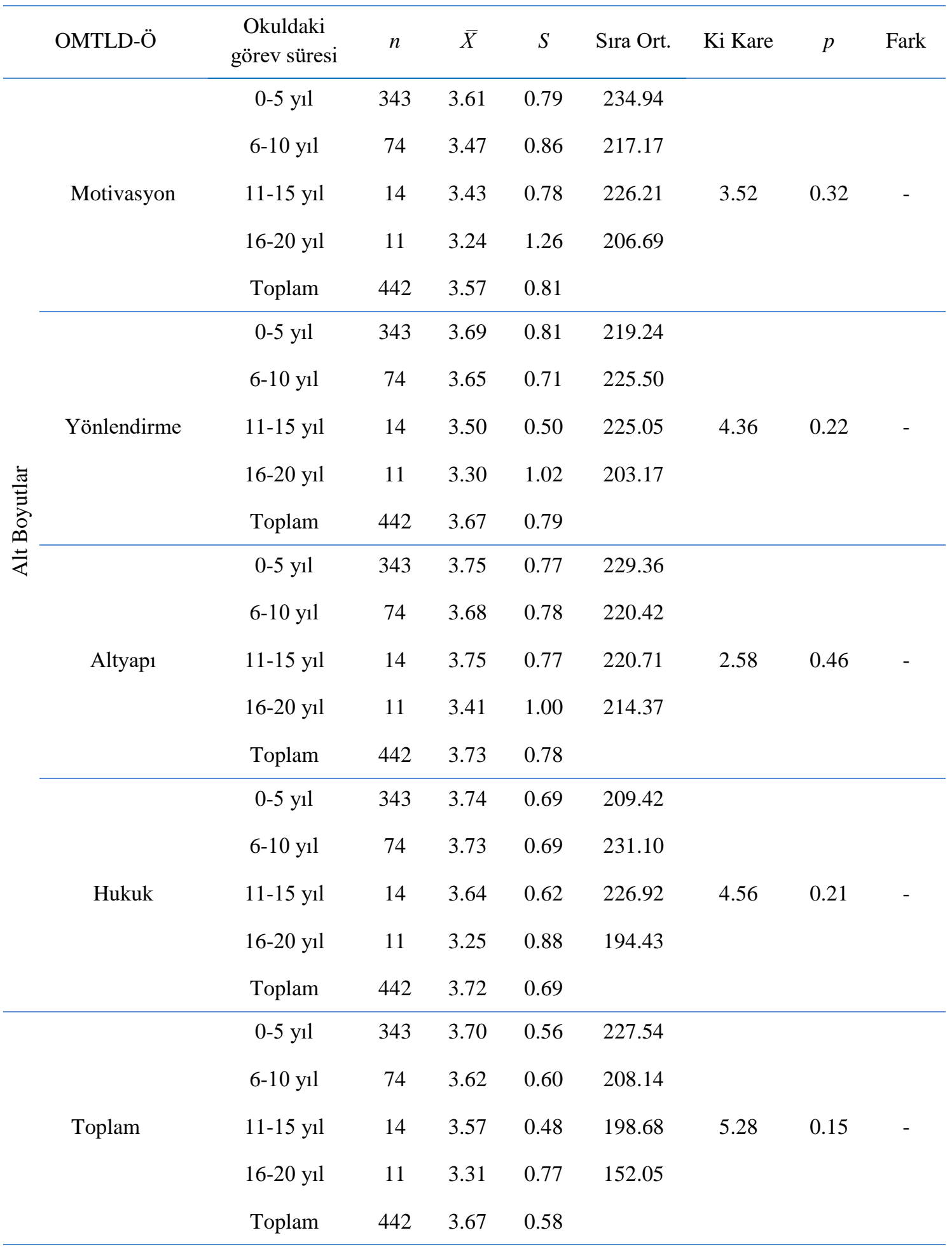

Tablo 11'den anlaşılabileceği üzere, çalışma grubunu oluşturan öğretmen görüşlerinde; öğretmenlerin teknoloji kullanımında okul müdürlerinin sergilediği teknolojik liderlik davranışları düzeylerinin toplamı ve boyutları ortalama puanları temelinde, okuldaki görev süresi değişkeninin alt grupları arasında istatistiki açıdan anlamlı bir farklılık tespit edilmemiştir ( $p>0.05)$. Görüşlerin en yüksek olduğu ortalama puanı $(\bar{X}=3.75)$ ile 0-5 yıl aralığı grubunda altyapı boyutunda iken, en düşük ise 
( $\bar{X}=3.24)$ ile motivasyon boyutunda $16-20$ y1l aralığı grubundadır. Okuldaki görev süresi değişkeninin bazı gruplarında, teknolojik liderlik davranışları düzeylerinin toplamı ve boyutlarına ilişkin öğretmen görüşleri ortalama puanları "Kararsızım (2.61-3.40)" aralığında iken, diğerlerinde "Katılıyorum (3.41-4.20)" aralığında değişmektedir.

Okuldaki görev süreleri farklı öğretmenlere göre; öğretmenlerin okulda teknoloji kullanımında, okul müdürlerinin sergilediği teknolojik liderlik davranışları toplamı ve dört alt boyutunun katıliyorum düzeyinde gerçekleştiği ifade edilebilir. Bir önceki ifadede, altyapı boyutu hariç diğer boyutlarda, 16-20 yıl alt grubu hariç alt gruplarının hepsinde yer alan öğretmen görüşleri dikkate alınmıştır. Altyapı boyutu hariç diğer boyutlarda ve teknolojik liderlik davranışları toplamı bağlamında, 16-20 yıl alt grubunda yer alan öğretmenlere göre; okul müdürlerinin sergilediği teknolojik liderlik davranışları toplamının kararsızım düzeyinde gerçekleştiği ifade edilebilir. Bulundukları okulda görev yapma süreleri farklı olan öğretmenlerin, okul müdürlerinin bu davranış düzeylerinin toplamı ve dört alt boyutuna ilişkin görüşleri çoğunlukla birbirlerine çok yakın değerde çıkmıştır denilebilir.

\section{Öğretmenlerin Okul Müdürleriyle Çalışma Sürelerine Göre Okul Müdürlerinin Teknolojik Liderlik Davranışları}

Bu kısımda, okul müdürüyle çalışma süresi değişkeni bağlamında, öğretmenlerin görüşlerine göre öğretmenlerin teknoloji kullanımında okul müdürlerinin sergilediği motivasyon, yönlendirme, altyapı, hukuk ve teknolojik liderlik davranışları toplamı düzeylerine ilişkin bulgulara ve yorumlara yer verilecektir.

Tablo 12'den anlaşılabileceği üzere, öğretmenlerin teknoloji kullanımında okul müdürlerinin sergilediği motivasyon, yönlendirme, altyapı ve hukuk davranışlarına ilişkin öğretmen görüşlerinin ortalama puanları temelinde, okul müdürüyle çalışma süresi alt grupları (0-5 yıl ve 6-10 yıl) bağlamında, öğretmenlerin görüşleri arasında istatistiki açıdan anlamlı bir farklılık tespit edilmemiştir $(p>0,05)$. 0-5 yıl aralığında okul müdürü ile çalışan öğretmenlerin görüşlerinin en yüksek olduğu ortalama puanı $(\bar{X}$ $=3.74)$ ile altyapı boyutunda iken en düşük ise $(\bar{X}=3.60)$ ile motivasyon boyutundadır. Ayrıca, 6-10 yıl aralığında okul müdürü ile çalışan öğretmenlerin görüşlerinin en yüksek olduğu ortalama puanı $(\bar{X}=3.72)$ ile hukuk boyutunda iken en düşük ise $(\bar{X}=$ 3.33 ) ile motivasyon boyutundadır. Motivasyon boyutu, her iki grup aralığında yer alan öğretmen görüşlerine ilişkin puanının en düşük olduğu boyuttur. Sonuç olarak, motivasyon boyutu 6-10 yıl alt grubunda öğretmen görüşleri "Kararsızım (2.61-3.40)" aralığında iken diğerlerinde "Katılıyorum (3.41-4.20)" aralığında değişmektedir.

Okul müdürüyle çalışma süreleri farklı olan öğretmenlere göre; öğretmenlerin okulda teknoloji kullanımında, okul müdürlerinin sergilediği teknolojik liderlik davranışları toplamının ve dört alt boyutunun katılıyorum düzeyinde gerçekleştiği ifade edilebilir. Bir önceki ifadede, motivasyon boyutu 6-10 y1l alt grubu hariç bütün boyutların alt gruplarının hepsinde yer alan öğretmen görüşleri dikkate alınmıştır. Motivasyon boyutu 6-10 y1l alt grubunda yer alan öğretmenlere göre; okul müdürlerinin sergilediği teknolojik liderlik davranışları düzeylerinin kararsızım düzeyinde gerçekleştiği ifade edilebilir. 
Tablo 12

Okul Müdürüyle Çalışma Süresi Değişkenine Göre OMTLD-Ö Toplamı ve Boyutlarına İlişkin Öğretmen Görüşlerinin Aritmetik Ortalama $(\bar{X})$, Standart Sapma (S), Mann Whitney U Testi Değerleri

\begin{tabular}{|c|c|c|c|c|c|c|c|c|c|}
\hline & OMTLD-Ö & $\begin{array}{c}\text { Okul } \\
\text { Müdürüyle } \\
\text { Çalışma } \\
\text { Süresi }\end{array}$ & $n$ & $\bar{X}$ & $S$ & $\begin{array}{l}\text { Sira } \\
\text { Ort. }\end{array}$ & $U$ & $p$ & Fark \\
\hline \multirow{15}{*}{ 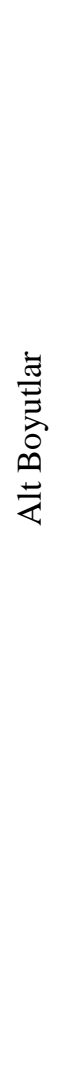 } & \multirow{3}{*}{ Motivasyon } & $0-5$ y1l & 403 & 3.60 & 0.80 & 225.10 & \multirow{3}{*}{6409.00} & \multirow{3}{*}{0.06} & \multirow{3}{*}{-} \\
\hline & & $6-10$ y1l & 39 & 3.33 & 0.93 & 184.33 & & & \\
\hline & & Toplam & 442 & 3.57 & 0.81 & & & & \\
\hline & \multirow{3}{*}{ Yönlendirme } & $0-5$ y1l & 403 & 3.67 & 0.79 & 222.03 & \multirow{3}{*}{7643.00} & \multirow{3}{*}{0.78} & \multirow{3}{*}{-} \\
\hline & & $6-10$ y1l & 39 & 3.64 & 0.81 & 215.97 & & & \\
\hline & & Toplam & 442 & 3.67 & 0.79 & & & & \\
\hline & \multirow{3}{*}{ Altyap1 } & $0-5$ y1l & 403 & 3.74 & 0.75 & 222.60 & \multirow{3}{*}{7414.50} & \multirow{3}{*}{0.56} & \multirow{3}{*}{-} \\
\hline & & $6-10$ y1l & 39 & 3.61 & 0.98 & 210.12 & & & \\
\hline & & Toplam & 442 & 3.73 & 0.78 & & & & \\
\hline & \multirow{3}{*}{ Hukuk } & $0-5$ y1l & 403 & 3.72 & 0.68 & 221.50 & \multirow{3}{*}{7858.00} & \multirow{3}{*}{1.00} & \multirow{3}{*}{-} \\
\hline & & $6-10$ y1l & 39 & 3.72 & 0.81 & 221.51 & & & \\
\hline & & Toplam & 442 & 3.72 & 0.69 & & & & \\
\hline & \multirow{3}{*}{ Toplam } & $0-5$ y1l & 403 & 3.68 & 0.56 & 224.19 & \multirow[t]{3}{*}{6776.00} & \multirow[t]{3}{*}{0.16} & \\
\hline & & $6-10$ y1l & 39 & 3.55 & 0.75 & 193.74 & & & \\
\hline & & Toplam & 442 & 3.67 & 0.58 & & & & \\
\hline
\end{tabular}

\section{Sonuç ve Tartışma}

İçinde bulunduğumuz çağda teknoloji ve bilgi, bir toplumun her alanında, gerek bireysel düzeyde gerekse örgütsel düzeyde önemli bir yere sahiptir. Teknoloji ve bilgi üretiminde önde olan toplumlar gelişme ve ekonomik büyüme açısından da diğer toplumların önüne geçebilmektedir. Bu temelde başta bir toplumun ekonomik, sosyal ve kültürel dinamikleri olmak üzere her türlü büyüme ve gelişme çabaları için gerekli nitelikli insan gücünü sağlaması amacıyla eğitim örgütüne yetki, rol ve sorumluluklar verilmektedir. $\mathrm{Bu}$ insan gücünü yetiştirme noktasında öğretmenlere büyük görev düşmektedir. Eğitim örgütlerinin esas iş görenleri olan öğretmenleri yönlendiren, güdüleyen ve önderlik eden temel etmenlerin başında okul yöneticileri gelmektedir. $\mathrm{Bu}$ bağlamda, okullarda üst düzey roller üstlenen okul yöneticilerinin, okul örgütünü daha verimli ve etkili kılmak amacıyla öğretmenlerin teknoloji kullanımında teknolojik liderlik davranışlarını üst düzeyde sergileyebilecek yetkinlikte olabilmeleri adına teknolojik liderlik davranışlarını etkili, verimli ve ideal bir şekilde kazanma ve geliştirme ihtiyacı üzerine odaklanılmıştır.

Bu çalışmada; 2017-2018 eğitim öğretim y1lı bahar döneminde Ankara Mamak İlçesindeki ortaokullarda çalışan öğretmenlerin görüşlerine göre; öğretmenlerin teknoloji kullanımında okul müdürlerinin sergilediği motivasyon, yönlendirme, altyapı, 
hukuk ve teknolojik liderlik davranışları toplamının düzeyleri tespit edilmiştir. $\mathrm{Bu}$ düzeylerde, öğretmenlerin cinsiyet, yaş, mesleki kıdem, öğrenim durumu, okuldaki görev süresi ve okul müdürüyle çalışma süresi değişkenleri alt grupları arasında istatistiki açıdan anlamlı farklılık olup olmadığı da uygun yöntem kullanılarak çözümlenmiştir.

$\mathrm{Bu}$ çalışma sonucuna göre; öğretmenler, öğretmenlerin teknoloji kullanımında okul müdürünün teknolojik liderlik davranışları sergilediğine genel bağlamda katılmaktadırlar. Ayrıca, öğretmenler, okul müdürünün teknolojik liderlik davranışları sergilediğine motivasyon, yönlendirme, altyapı ve hukuk alt boyutları bağlamında da katılmaktadırlar. Öğretmenlerin, öğretmenlerin teknoloji kullanımında okul müdürünün teknolojik liderlik motivasyon davranışına katılmaları, Turan'ın (2002) okul müdürünün rolleri arasında yer verdiği; öğrenim ve öğretim sürecinin etkili olarak gerçekleştirilmesi için astlarına destek ve yön vermesi görüşünü desteklemektedir. Ayrıca, öğretmenlerin teknolojik liderlik motivasyon davranışına - "Okulda teknoloji kullanımıma ilişkin endişelerimi gidermeye çalışır” maddesi gibi altı maddelerden oluşan bu boyut katılmaları; Meral, Zereyak ve Cambaz'ın (2001) bilinmeyen bir şeye karşı hissedilen genel korku durumu, bireylerde bilgisayarı kullanmaya karşı bir korku oluşturma için de geçerlidir ve bu korku, bilgisayarı kullandıkça ortadan kalkabilir görüşleriyle ilişkili bir sonuç olarak değerlendirilebilir görüşünü de desteklemektedir.

Görüşü alınan kadın öğretmenler ile erkek öğretmenler; öğretmenlerin teknoloji kullanımında okul müdürünün teknolojik liderlik davranışları sergilediğine, genel bağlamda ve motivasyon, yönlendirme, altyapı ve hukuk olmak üzere bütün alt boyutları bağlamında katılmaktadır. Ayrıca, öğretmenlerin cinsiyeti; öğretmenlerin teknoloji kullanımında okul müdürlerinin sergilediği teknolojik liderlik davranışları noktasında, genel bağlamda ve motivasyon, yönlendirme, altyapı ve hukuk olmak üzere bütün alt boyutlar bağlamında görüş farklılığı oluşturmamıştır. Bu sonuç ile benzer bir sonuç olarak; Cantürk ve Aksu (2017), öğretmenlerin okul müdürlerinin teknolojik liderlik davranışına ilişkin görüşlerinde öğretmenlerin cinsiyetine göre anlamlı fark olmadığını tespit etmişlerdir. Cantürk ve Aksu'nun (2017) kullandığ1 ölçeğin kullanıldığı bir diğer benzer çalışmada benzer bir sonuç olarak; Ulukaya (2015), okul yöneticilerinin teknoloji liderliği öz-yeterlik algılarının da cinsiyete göre bütün boyutlar ve ölçek genelinde değişmediğini tespit etmiştir. Cantürk ve Aksu (2017) ve Ulukaya (2015)'ın kullandığı ölçeğin kullanıldığı bir diğer benzer çalışmada benzer bir sonuç olarak; Görgülü (2013) ve Demirsoy (2016), öğretmenlerin görüşleri temelinde okul yöneticilerinin teknolojik liderlik yeterlik düzeyinin öğretmenlerin cinsiyetine göre bütün boyutlar ve ölçek genelinde değişmediğini tespit etmiştir. Cantürk ve Aksu (2017), Ulukaya (2015), Görgülü (2013) ve Demirsoy’un (2016) kullandığı ölçeğin kullanıldığı bir diğer benzer çalışmada benzer bir sonuç olarak; Hayytov (2013) da okul yöneticilerin teknoloji liderliği yeterlik algı düzeylerinin cinsiyete göre değişmediğini tespit etmiştir. Bir diğer benzer çalışmada; Sincar (2009), sınıf öğretmenlerinin ilköğretim okulu yöneticilerinin teknoloji liderliği rolleri arasında yer alan vizyon boyutu hariç, insan merkezlilik, iletişim ve işbirliği ile destek boyutlarına ilişkin görüşlerinde cinsiyetin göre anlamlı fark yaratan bir etken olmadığını belirtmiştir. Sincar'ın (2009) ölçeğinin kullanıldı̆̆ı bir diğer benzer çalışmada; Ölçek (2014), ilköğretim okulu müdürlerinin teknoloji liderliği düzeylerine ilişkin öğretmen görüşlerinin cinsiyete göre değişmediğini tespit etmiştir. Teknolojik liderlik konusunun 
değişik boyutlarının çalışıldığı benzer araştırmalardaki sonuçlar göstermektedir ki cinsiyet değişkeni teknolojik liderlik davranışlarını çözümlemede genel olarak anlamlı bir fark oluşturmamaktadır.

Görüşü alınan farklı yaş gruplarında öğretmenler; öğretmenlerin teknoloji kullanımında okul müdürünün teknolojik liderlik davranışları sergilediğine, genel bağlamda ve motivasyon, yönlendirme, altyapı ve hukuk olmak üzere bütün alt boyutlar bağlamında katılmaktadır. Ayrıca, öğretmenlerin yaşı; öğretmenlerin teknoloji kullanımında okul müdürlerinin sergilediği teknolojik liderlik davranışları noktasında, genel bağlamda ve motivasyon, yönlendirme, altyapı ve hukuk olmak üzere bütün alt boyutlar bağlamında görüş farklılığı oluşturmamıştır. Bu sonuç ile benzer bir sonuç olarak; Ulukaya (2015), okul yöneticilerinin teknoloji liderliği öz-yeterlik algılarının da öğretmenlerin yaşları temelinde bütün boyutlarda ve ölçek genelinde değişmediğini tespit etmiştir. Demirsoy'un (2016) kullandığı ölçeğin kullanıldığı bir diğer benzer çalışmada benzer bir sonuç olarak; Hayytov (2013), okul yöneticilerin teknoloji liderliği yeterlik algı düzeylerinin öğretmenlerin yaşına göre değişmediğini tespit etmiştir. Diğer bir benzer çalışmada farklı bir sonuç olarak; Demirsoy (2016), öğretmenlerin görüşleri temelinde okul yöneticilerinin teknolojik liderlik yeterlik düzeyinin farklı yaş gruplarındaki öğretmenlere göre farklılaştığını tespit etmiştir.

Görüşü alınan farklı mesleki kıdem gruplarındaki öğretmenler; öğretmenlerin teknoloji kullanımında okul müdürünün teknolojik liderlik davranışları sergilediğine, genel bağlamda ve motivasyon, yönlendirme, altyapı ve hukuk olmak üzere bütün alt boyutlar bağlamında katılmaktadır. Ayrıca, öğretmenlerin mesleki kıdemi; öğretmenlerin teknoloji kullanımında okul müdürlerinin sergilediği teknolojik liderlik davranışlarının geneli bağlamında ve motivasyon, yönlendirme, altyapı ve hukuk olmak üzere bütün alt boyutları bağlamında görüş farklılığı oluşturmamıştır. Bu sonuç ile benzer bir sonuç olarak; Cantürk ve Aksu (2017), öğretmenlerin okul müdürünün teknolojik liderlik davranışına - konu bu çalışma kapsamındaki ölçekten farklı boyutlar altında çözümlenmiştir - ilişkin görüşlerinde öğretmenlerin mesleki kıdemlerine göre anlamlı fark olmadığını tespit etmişlerdir. Ayrıca, bir diğer benzer çalışmada; Sincar (2009), ilköğretim okulu yöneticilerinin teknoloji liderliği rolleri arasında yer alan insan merkezlilik, vizyon, iletişim ve işbirliği ile destek boyutlarına ilişkin sınıf öğretmenleri görüşlerinde mesleki kıdeme göre anlamlı fark olduğunu tespit etmiştir. Sincar'ın (2009) ölçeğinin kullanıldığı bir diğer benzer çalışmada; Ölçek (2014), ilköğretim okulu müdürlerinin teknoloji liderliği düzeylerine ilişkin öğretmen görüşlerinin mesleki kıdeme göre değişmediğini tespit etmiştir. Diğer bir benzer çalışmada farklı bir sonuç olarak; Demirsoy (2016), öğretmenlerin görüşleri temelinde okul yöneticilerinin teknolojik liderlik yeterlik düzeyinin farklı mesleki kıdem gruplarından öğretmenlere göre farklılaştı̆̆ını tespit etmiştir.

Görüşü alınan lisans eğitimi gören öğretmenler ile lisansüstü eğitimi gören öğretmenler; öğretmenlerin teknoloji kullanımında okul müdürünün teknolojik liderlik davranışları sergilediğine, genel bağlamda ve motivasyon, yönlendirme, altyapı ve hukuk olmak üzere bütün alt boyutlar bağlamında katılmaktadır. Ayrıca, öğretmenlerin öğrenim; öğretmenlerin teknoloji kullanımında okul müdürlerinin sergilediği teknolojik liderlik davranışlarının geneli bağlamında ve motivasyon, yönlendirme, altyapı ve hukuk olmak üzere bütün alt boyutlar bağlamında görüş farklılığı oluşturmamıştır. Bu sonuç ile benzer bir sonuç olarak; Cantürk ve Aksu (2017), öğretmenlerin okul 
müdürlerinin teknolojik liderlik davranışına - her ne kadar konu farklı boyutlar altında çözümlenmiş olsa da - ilişkin görüşlerinde öğretmenlerin öğrenim durumuna göre anlamlı fark olmadığını tespit etmişlerdir. Cantürk ve Aksu'nun (2017) kullandığ ölçeğin kullanıldığı bir diğer benzer çalışmada benzer bir sonuç ile Ulukaya (2015), okul yöneticilerinin teknoloji liderliği öz-yeterlik algılarının da öğrenim durumuna göre bütün boyutlar ve ölçek genelinde değişmediğini tespit etmiştir. Sincar'ın (2009) ölçeğinin kullanıldığı bir diğer benzer çalışmada; Ölçek (2014), ilköğretim okulu müdürlerinin teknoloji liderliği düzeylerine ilişkin öğretmen görüşlerinin de öğrenim durumuna göre değişmediğini tespit etmiştir.

16-20 yıl arasında bulunduğu okulda görev yapan öğretmenler, öğretmenlerin teknoloji kullanımında okul müdürünün teknolojik liderlik davranışları sergilediğine, genel bağlamda ve motivasyon, yönlendirme, altyapı ve hukuk olmak üzere bütün alt boyutlar bağlamında kararsızken, altyapı boyutunda katılmaktadır. Ayrıca, okuldaki görev süresi değişkeninin diğer gruplarında yer alan öğretmenler; öğretmenlerin teknoloji kullanımında okul müdürünün teknolojik liderlik davranışları sergilediğine, genel bağlamda ve motivasyon, yönlendirme, altyapı ve hukuk olmak üzere bütün alt boyutlar bağlamında katılmaktadır. Ancak, öğretmenlerin okuldaki görev süresi; öğretmenlerin teknoloji kullanımında okul müdürlerinin sergilediği teknolojik liderlik davranışlarının geneli bağlamında ve motivasyon, yönlendirme, altyapı ve hukuk olmak üzere bütün alt boyutları bağlamında istatistiki temelde anlamlı görüş farklılı̆̆ oluşturmamıştır.

Öğretmenlerin kararsız olduğu motivasyon boyutunda 6-10 y1l arasında okul müdürüyle çalışma süresi alt grubu hariç, 0-5 y1l ve 6-10 yıl gruplarında okul müdürüyle çalışan öğretmenler, öğretmenlerin teknoloji kullanımında okul müdürünün teknolojik liderlik davranışları sergilediğine, genel bağlamda ve motivasyon, yönlendirme, altyapı ve hukuk olmak üzere bütün alt boyutlar bağlamında katılmaktadır. Ancak, öğretmenlerin okul müdürüyle çalışma süresi; öğretmenlerin teknoloji kullanımında okul müdürlerinin sergilediği teknolojik liderlik davranışlarının geneli bağlamında ve motivasyon, yönlendirme, altyapı ve hukuk olmak üzere bütün alt boyutları bağlamında istatistiki temelde anlamlı görüş farklılığı oluşturmamıştır, sadece motivasyon boyutunda 0-5 yıl ile 6-10 yıl gruplarında fark olmaya çok yakın bir sonuç elde edilmiştir.

Özetle, bu çalışma ile maddelerinin tamamının literatürden ulaşılan bilgilere dayandırıldığı; motivasyon, yönlendirme, altyapı ve hukuk boyutlarından oluşan yeni güncel bir ölçme aracı ile teknolojik liderlik konusuna yeni bir uygulamalı çözümleme yaklaşımı sunularak literatüre bilgi kazandırılmıştır. Son olarak, günümüz Türkiye'sinin eğitim - MEB merkez teşkilatında, büyük bir şehrin lüks bir semtindeki bir devlet okulunda, özel okulda veya Türkiye'nin herhangi bir ücra bölgesindeki taşra örgütünde, bir okulda - örgütünün örgütsel amaçlarında, yapısında, işleyişinde, ikliminde, kültüründe ve örgütsel davranışlarda güncel olan veya olmayan teknolojilerin varlığından rahatlıkla söz edilebilir. Temel çağdaş teknolojiler arasında; öğretmen, öğrenci ve eğitim yöneticileri bilgi yönetim sistemleri, sınıf içi etkinliklerde kullanılmak üzere etkileşimli tahtalar, tablet, tepegöz ve internet gibi teknolojiler yer almaktadır. Eğitim ve öğretim amaçlarını gerçekleştirmek amacıyla bu teknolojilerin okul örgütünün örgütsel ve yönetimsel faaliyetlerinde kullanımı noktasında izleyenlere önderlik etme gerçeği mevcuttur. Bu ortamda, okulun ve okul yöneticisinin başarılı 
olabilmesi için yöneticilerin ortama ayak uydurabilme yeteneğinin üst düzeyde olması gerekebilir. Bu teknolojilerin kullanımına ilişkin uygun ve gerekli uygulama, tedbir ve strateji politikalarının oluşturulması, yol gösterimi ve eğitim örgütleri yönetim süreçlerine, çalışanlarına ve öğrencilere ilgililerce sağlanması gerekebilir. Bu bağlamda, bu araştırma bu ihtiyacın giderilmesine katkı sağlama potansiyeli taşıyabilir.

Bu bağlamda bu ihtiyacın giderilmesine katkı sağlama noktasında; bu çalışma ile motivasyon, yönlendirme, altyapı ve hukuk boyutları temelinde oluşturulan teknolojik liderlik bilgi kümesi özellikle öğretmenlerce teknolojinin kullanımı temelinde okul yöneticilerinin sergilemesi gereken teknolojik liderlik davranışları noktasında eğitim öğretim politika yapıcılarına, araştırmacılara, okul ve eğitim yöneticilerine bilgi sağlama potansiyeli taşımaktadır.

$\mathrm{Bu}$ sonuçlar temelinde; bu okullarda verilerin toplandığı zaman diliminde okul müdürlerinin teknolojik liderlik davranışlarını sergiledikleri oranda astları olan öğretmenlerle iletişimlerinin iyi olabileceği çıkarımına da varılabilir. Bu okullarda görevli okul müdürlerinin bu davranışları çoğunlukla sergilemeleri bağlamında, E-Okul ve MEBBİS gibi MEB'in öğrenci, öğretmen, çeşitli istatistik vb. iş ve işlemleri için geliştirdiği uygulamaların öğretmenlerce kullanımının yaygın olabileceği çıkarımı da yapılabilir. $\mathrm{Bu}$ sonuçların, bu okullarda görev yapan, okul müdürlerinin ve öğretmenlerin çoğunun bilgisayar, tepegöz gibi bazı teknolojik gereçleri doğru ve verimli bir biçimde kullanma noktasında çoğunlukla başarılı olduklarına ilişkin de ipuçları barındırdı ğı ifade edilebilir.

Diğer bir çıkarım olarak, bu okulların işleyiş, iklim ve kültürlerinde teknolojinin varlığından da söz edilebilir. Türkiye'de gerçekleştirilen teknolojinin eğitimle bütünleştirilmesi projelerinin, özellikle 2011 yılında başlatılan (EĞİTEK, 2011) ve Türkiye Eğitim Sistemi'nde en büyük ve kapsamlı biçimde teknolojinin eğitimle bütünleştirilme uğraşısı olan FATIHH projesinin amaçlarının belirli bir düzeyde gerçekleştirildiğine ilişkin bir yorum için de dayanak olabilir. Bu noktada, öğretmenlerden veri toplama sürecinde, araştırmacı tarafinca çalışma grubunu oluşturan ortaokullarda FATİH projesinin teknolojik gereçlerinin okul ile bütünleştirildiği ve okullarda teknoloji yoğun bir ortam oluşturulduğuna ilişkin bazı gözlemlenebilir teknolojilerin tespit edilmesi bu çıkarları destekleyen bir diğer noktadır.

\section{Öneriler}

Öğretmenlerin teknoloji kullanımında okul müdürlerinin sergilediği teknolojik liderlik davranışları, ortaokul öğretmenlerinin görüşlerinden farklı olarak, kırsal ve şehir bölgelerinde yer alan resmi ve özel çeşitli okul türlerinde farklı eğitim iş görenleri veya öğrencilerden oluşan katılımcılar (örneklem grupları) üzerinde doğrulayıcı faktör analizi ve güvenirlik çalışmaları gerçekleştirilerek konular çözümlenebilir.

Bu çalışmada okul müdürü davranışı temelinde çözümlenen teknolojik liderlik konusu örgütsel bağlamda çözümlenebilir. Yani çeşitli ortaokul veya lise tipinde okul örgütlerinin örgütsel davranışı incelenebilir. Ölçek maddelerinde "okul müdürümüz..." yerine "okulumuzda..." şeklinde ifadelere yer verilebilir.

Öğretmenlerin teknoloji kullanımında okul müdürlerinin sergilediği teknolojik liderlik davranışları konusu, eğitim bilimleri başta olmak üzere diğer yönetim bilimleri ve diğer ilgili disiplinlerdeki örgütsel davranış, liderlik, yönetim kuramları, performans gibi konularla çalışılabilir. 
MEB merkez teşkilatında, il ve ilçe milli eğitim yapılarında okul müdürlerine teknolojik liderlik konusunda danışmanlık sağlama için ehil kurullar oluşturulabilir. Okul müdürlerinin teknolojik liderlik konusunda iyi örnekler vb. bilgi paylaşımlarında bulunabilecekleri sosyal medya ağ yapıları kurulabilir. 


\section{Summary}

Introduction: Technological leadership is the leadership in the subject of ensuring the benefits of technology at the highest level of effectiveness in creating and sustaining an effective education and training system. In this study, the meaning attached to technological leadership; leadership in information technology, leadership in information and communication technologies, leadership in electronic technology, leadership in educational technology, and digital leadership.

Purpose and Significance: This research aims to examine the level of technological leadership behaviors of the secondary school principals in the use of technology by teachers according to secondary school teachers' views on the basis of some variables (gender, age, working experience, education status, working-years spent in the same school, and the duration of working with the principal). It is significant that a new, upto-date, applied technological leadership analysis approach and so knowledge was needed to be introduced to the literature through using a new, up-to-date applied technological leadership scale which includes motivation, orientation, precaution, and support.

Methods: Quantitative data collection and analysis have been carried out in order to solve the research problem. The study group consisted of teachers from the secondary schools in Mamak district of Ankara city during the spring semester of the 2017-2018 academic years. The data was collected through "School Principals Technological Leadership Behavior Scale (SPTLB-S)" developed by Durnal1 (2018). The scale is of Likert type 5. The SPTLB-S consists of eighteen items under four factors which are motivation, orientation, precaution, and support.

In the analysis of the data; descriptive statistical methods such as mean, frequency, and standard deviation, and the result, meaning, significant difference statistical methods such as t-test was used. The normality and variance equality tests of the general data and data subgroups obtained from scales required for assumption in order to determine the type of parametric and non-parametric test were performed separately for the study's each purpose. If $\mathrm{p}$ (probability) value is less than 0.05 (5\%), it is specified that there is a meaningful difference in the finding.

Results: According to the main result; teachers' views regarding technological leadership behaviors of the secondary school principal in the use of technology by teachers is at a "high (4/5)" level for general and all sub-dimensions. There were no statistically meaningful differences found in terms of all variables (gender, age, working experience, education status, working-years spent in the same school, and the duration of working with the principal).

Discussion and Conclusions: It is obvious that up-to-date or non-current technologies have been integrated into today's education of Turkey - both in the central organization of the Ministry of National Education and local organizations such as schools - whether they are private or state - whether it is in a suburb or in an upscale neighborhood of a big city or rural areas in any remote distance of Turkey. Especially, they have been 
integrated into the organizational goals of the organization, the structure, the functioning of the climate, culture and in organizational behavior. Basic contemporary technologies include; information management systems (such as information of teachers, students, and administrators), interactive boards for the use in class activities, tablets, overhead projectors, and the Internet. There is the fact that there is a need for leading school personnel (the followers) to use technologies in the organizational and managerial activities of the school organization in order to realize the educational and teaching goals effectively in such technology reach school environment. In order to make school and school administrators successful in this environment, it is necessary to establish appropriate and necessary policies, precaution, and strategies for the use of these technologies as well as the necessity of this ability to keep up with the organization and to provide guidance and training organizations to the management processes. In this context, contributing to the elimination of this need, this study has the potential to provide information to policymakers, researchers, schools, and education managers at the point of technological leadership behaviors that school administrators should exhibit, especially on the basis of the use of technology by teachers, based on motivation, orientation, infrastructure, and legal dimensions.

As the suggestion, the topic can be carried out by using School Principals Technological Leadership Behavior Scale on the sample groups of different personnel or students in state and private school types in rural areas and cities -not like in this study like secondary school teachers- through Confirmatory Factor Analysis and reliability studies. Lastly, it is important to note how the technological leadership behaviors which principal should exhibit in the use of technology by teachers, should be examined in the school manager training programs, in the in-service courses, and in the education faculties for the use of school principals, prospective principals and teachers and teacher candidates. 


\section{Kaynakça}

Ağaoğlu, E., Ceyhan, E., Ceyhan, A., \& Şimşek, Y. (2008). The validity and reliability studies of the computer anxiety scale on educational administrators [Elektronik versiyon]. Turkish Online Journal of Distance Education - TOJDE July, 9(3), Article 4.

Altunışık, R., Coşkun, R., Bayraktaroğlu, S., \& Yıldırım, E. (2010). Sosyal bilimlerde araştırma yöntemleri: SPSS uygulamalı. Sakarya: Sakarya Yayıncılık.

Anderson, R. E., \& Dexter, S. (2005). School technology leadership: An empirical investigation of prevalence and effect. Educational Administration Quarterly, 41(1), 49-82.

Balaban-Uysal, N. (2012). Okul yöneticilerinin teknoloji liderliği rolleri ile bilgisayar kaygı düzeyleri arasındaki ilişkinin belirlenmesi (Yayımlanmamış Yüksek Lisans Tezi). Anadolu Üniversitesi, Eğitim Bilimleri Enstitüsü. Eskişehir.

Baş, E. D. (2012). Illköğretim okulu yöneticilerinin teknoloji liderliği rolleriyle okul iklimi arasındaki ilişki (Yayımlanmamış Yüksek Lisans Tezi). Maltepe Üniversitesi, Sosyal Bilimler Enstitüsü, İstanbul.

Bektaş, F. (2014). School principals' personal constructs regarding technology: An analysis based on decision-making grid technique. Educational Sciences: Theory and Practice, 14(5), 1767-1775.

Bostancı, H. (2010). Okul yöneticilerinin teknolojik liderlik yeterlilikleri açısından incelenmesi (Yayımlanmamış Yüksek Lisans Tezi). Gazi Üniversitesi, Bilişim Enstitüsü, Ankara.

Can, T. (2008). İlköğretim okulları yöneticilerinin teknolojik liderlik yeterlilikleri: Ankara ili Etimesgut ilçesi örneği. 8th International Educational Technology Conference. Eskişehir, 06-09 Mayıs 2008.

Cantürk, G. (2016). Okul yöneticilerinin teknolojik liderlik davranışları ve bilişim teknolojilerinin yönetim süreçlerinde kullanımı arasındaki ilişki (Yayımlanmamış Doktora Tezi). Akdeniz Üniversitesi, Eğitim Bilimleri Enstitüsü, Antalya.

Cantürk, G., \& Aksu, T. (2017). Okul yöneticilerinin teknolojik liderlik davranışları. Ĕ̈itim ve Öğretim Araştırmaları Dergisi, 6(4), 21-38.

Chang, I. H. (2012). The effect of principals' technological leadership on teachers' technological literacy and teaching effectiveness in Taiwanese elementary schools. Educational Technology \& Society, 15(2), 328-340.

Creighton, T. (2003). The principal as technology leader. Thousand Oaks, California: Corwin Press.

Demir, E., Saatçioğlu, Ö., \& İmrol, F. (2016). Uluslararası dergilerde yayımlanan eğitim araştırmalarının normallik varsayımları açısından incelenmesi. Current Research in Education, 2(3), 130-148.

Demirsoy, S. (2016). Okul yöneticilerinin teknolojik liderlik yeterlikleri ile ögretmenlerin teknolojik pedagojik bilgi düzeyleri arasındaki ilişki (Yayımlanmamış Yüksek Lisans Tezi). İstanbul Sabahattin Zaim Üniversitesi, Sosyal Bilimler Enstitüsü, İstanbul. 
Durnalı, M. (2018). Öğretmenlere göre okul müdürlerinin teknolojik liderlik davranışları ve bilgi yönetimini gerçekleştirme düzeyleri (Doktora Tezi). Hacettepe Üniversitesi, Eğitim Bilimleri Enstitüsü, Ankara.

EĞİTEK (2011). Eğitimde Fatih Projesi için imzalar atıldı. Eğitim Teknolojileri Genel Müdürlüğ̈̈ Elektronik Dergisi, 1. http://yegitek.meb.gov.tr/elektronikdergi/20 11/ocak/files/ydergii.pdf adresinden erişilmiştir.

Engür, A. (2014). Teknoloji öğretmenlerinin okul müdürlerinin teknolojik liderik becerileri hakkındaki görüşleri (Yayımlanmamış Yüksek Lisans Tezi). Akdeniz Üniversitesi, Eğitim Bilimleri Enstitüsü, Antalya.

Ergişi, K. (2005). Bilgi teknolojilerinin okulda etkin kullanımı ile ilgili okul yöneticilerinin teknolojik yeterliklerinin belirlenmesi (Kırlkkale ili örneği) (Yayımlanmamış Yüksek Lisans Tezi). Kırıkkale Üniversitesi, Sosyal Bilimler Enstitüsü, Kırıkkale.

Erkuş, A. (2005). Bilimsel araştırma sarmalı. Ankara: Seçkin Yayıncılık.

Ertuğrul, E. (2014). Illköğretim okullarında görev yapan öğretmenlerin görüşlerine göre yöneticilerin teknoloji liderlik düzeyi ile yönetici etkililiği arasındaki iliş̧i (Yayımlanmamış Yüksek Lisans Tezi). Uşak Üniversitesi, Sosyal Bilimler Enstitüsü, Uşak.

Field, A. (2009). Discovering statistics using SPSS (Third Edition). London: SAGE Press.

Görgülü, D. (2013). Bilgi toplumuna geçiş sürecinde okul yöneticilerinin teknolojik liderlik yeterlilikleri açısından incelenmesi (Konya ili örneği) (Yayımlanmamış Yüksek Lisans Tezi). Atatürk Üniversitesi, Eğitim Bilimleri Enstitüsü, Erzurum.

Gültekin, F. (2013). Ortaöğretim yöneticilerinin teknoloji liderliği - özyeterlik algıları (Yayımlanmamış Yüksek Lisans Tezi). Marmara Üniversitesi, Eğitim Bilimleri Enstitüsü, İstanbul.

Gürkan-Beyaz, G. (2014). Teknik ve endüstri meslek lisesi yöneticilerinin teknoloji liderliği davranışları (Diyarbakır ili örneği) (Yayımlanmamış Yüksek Lisans Tezi). Zirve Üniversitesi, Sosyal Bilimler Enstitüsü, Gaziantep.

Hacıfazlığlu, Ö., Karadeniz, Ş., \& Dalgıç, G. (2010). Eğitim yöneticileri teknoloji liderliği standartlarına ilişkin öğretmen, yönetici ve denetmenlerin görüşleri. Kuram ve Uygulamada Ĕ̈itim Yönetimi Dergisi, 16(4), 537-577.

Hayytov, D. (2013). Eğitim yöneticilerinin teknoloji liderliği yeterlik algılar ile ögretmenlerin teknolojiye yönelik tutumları arasındaki ilişki (Yayımlanmamış Yüksek Lisans Tezi). Gazi Üniversitesi, Eğitim Bilimleri Enstitüsü, Ankara.

Hudanich, N. V. (2002). Identifying educational technology leadership competencies for new jersey's school superintendents (Unpublished Doctoral Dissertation). Seton Hall University, South Orange, New Jersey, United States.

International Society for Technology in Education (ISTE) (2009). ISTE standarts administrators. [Çevrim-içi: http://www.iste.org/docs/pdfs/2014_ISTE_Standards-A_PDF.pdf, Erişim tarihi: 14.08.2017.]

Irmak, M. (2015). Illkokul ve ortaokul öğretmenlerinin, yöneticilerinin "teknoloji liderliği” düzeylerine ilişkin algıları (Yayımlanmamış Yüksek Lisans Tezi). Pamukkale Üniversitesi, Eğitim Bilimleri Enstitüsü, Denizli. 
Kalaycı, Ş. (2010). SPSS uygulamalı çok değişkenli istatistik teknikler. Ankara: Asil Yayın Dağıtım.

Karasar, N. (2009). Bilimsel araştırma yöntemleri. Ankara: Nobel Yayınları.

Kearsley, G., \& Lynch, W. (1992). Educational leadership in the age of technology: The new skills. Journal of Research on Computing in Education, 25(1), 50-60.

Koçak, F., \& Helvacı, M. A. (2011). Okul yöneticilerinin etkililiği (Uşak ili örneği). Eğitim Bilimleri Araştırmaları Dergisi, 1(1), 33-55.

McKillup, S. (2012). Statistics explained: An introductory guide for life scientists (Second edition). Cambridge, UK: Cambridge University Press.

McLeod S., \& Richardson J. W. (2011). The dearth of technology leadership coverage. Journal of School Leadership, 21, 216-240.

Meral, M., Cambaz, H., \& Zereyak, E. (2001). Öğretmenlerin bilgisayara karşı tutumları ve bilgisayar kaygısı. Bilişim Teknolojileri Işı̆̆ında Eğitim Konferansı ve Sergisi, 3-5 Mayıs 2001. Ankara: ODTÜ-KKM.

Micheal, S. O. (1998). Best practices in information technology (IT) management: Insight from K-12 schools' technology audits. International Journal of Educational Management, 12(6), 277-288.

Ölçek, G. (2014). İlköğretim okullarında görev yapan müdürlerin teknoloji liderliği düzeylerine ilişkin okul müdürü ve ögretmenlerinin görüşlerinin incelenmesi (Yayımlanmamış Yüksek Lisans Tezi). Uşak Üniversitesi, Sosyal Bilimler Enstitüsü, Uşak.

Özdamar, K. (2004). Paket programlar ile istatistiksel veri analizi (5. Baskl). Eskişehir: Kaan Kitapevi

Öztaş, A. (2013). Resmi ortaöğretim okulu yöneticilerinin teknoloji liderliği rollerine ilişkin öğretmen görüşleri (Yayımlanmamış Yüksek Lisans Tezi). Marmara Üniversitesi, Eğitim Bilimleri Enstitüsü, İstanbul.

Scott, G. (2005). Educator perceptions of principal technology leadership competencies (Unpublished Doctoral Dissertation). The University of Oklahoma, Norman, Oklahoma, United States.

Shapiro, S. S., \& Wilk, M. B. (1965). An analysis of variance test for normality (complete samples). BIOMETRIKA, 52(3/4), 591-611.

Sincar, M. (2009). Illköğretim okulu yöneticilerinin teknoloji liderliği rollerine ilişkin bir inceleme (Gaziantep ili örneği) (Yayımlanmamış Doktora Tezi). İnönü Üniversitesi, Sosyal Bilimler Enstitüsü, Malatya.

Slowinski, J. (2000). Becoming a technologically savvy administrator. ERIC DIGEST, 135. EDO-EA-00-1.

Tanzer, S. (2004). Mesleki ve teknik öğretim okulu yöneticilerinin teknolojik liderlik yeterlikleri (Yayımlanmamış Yüksek Lisans Tezi). Abant İzzet Baysal Üniversitesi, Sosyal Bilimler Enstitüsü, Bolu.

The Office of Research Integrity (ORI) (2018). Descriptive studies. [Çevrim-içi: http://ori.hhs.gov/ education/products/sdsu/res_des1.htm, Erişim tarihi: 14.04.2018] 
Turan, S. (2002). Eğitim yöneticileri için teknolojik standartlar: Kavramsal bir çözümleme. Bilişim Teknolojileri Işığında Eğitim Konferansı ve Sergisi, Ankara: ODTÜ-KKM.

Ulukaya, F. (2015). Okul yöneticilerinin teknoloji liderliği özyeterlikleri ile ĕgitim ögretim işlerini gerçekleştirme düzeyleri arasındaki ilişki (Tokat ili örneği) (Yayımlanmamış Yüksek Lisans Tezi). Gaziosmanpaşa Üniversitesi, Eğitim Bilimleri Enstitüsü, Tokat.

Ünal, E., Uzun, A. M., \& Karataş, S. (2015). An examination of school administrators' technology leadership self-efficacy. Croatian Journal of Education-Hrvatski Casopis Za Odgoj I Obrazovanje, 17(1), 195-215.

Valdez, G. (2004). Critical issue: Technology leadership: Enhancing positive educational change. North Central Regional Educational Laboratory, 6(7), 12.

This is an Open Access article distributed under the terms of the Creative CommonsAttributionNonCommercial-ShareAlike 4.0 International (CC BY-NC-SA 4.0). For further information, you can refer to https://creativecommons.org/licenses/by-nc-sa/4.0/ 